\title{
Movements and diving behavior of Atlantic bluefin tuna Thunnus thynnus in relation to water column structure in the northwestern Atlantic
}

\author{
Gareth L. Lawson ${ }^{1,2, *}$, Michael R. Castleton ${ }^{1}$, Barbara A. Block ${ }^{1}$ \\ ${ }^{1}$ Tuna Research and Conservation Center, Stanford University, Hopkins Marine Station, 120 Oceanview Boulevard, \\ Pacific Grove, California 93950, USA \\ ${ }^{2}$ Present address: Biology Department, Woods Hole Oceanographic Institution, Woods Hole, Massachusetts 02543, USA
}

\begin{abstract}
We analyzed the movements and diving behavior in relation to water column structure of 35 electronically tagged Atlantic bluefin tuna (176 to $240 \mathrm{~cm}$ in length at tagging) during their spring-fall period of occupancy of the Gulf of Maine, Canadian Shelf, and neighboring off-shelf waters from 1999 to 2005. Tagged fish arriving in this study region in March-April initially occupied weakly stratified off-shelf waters along the northern Gulf Stream. As waters over the continental shelf warmed in June, the fish shifted onto the shelf. Sea surface temperatures occupied were relatively constant in both off- and on-shelf waters (April-September monthly medians varying from 16.1 to $19.0^{\circ} \mathrm{C}$ ). Dives made in the stratified waters of the shelf during summer and fall were significantly more frequent (up to 180 dives $\mathrm{d}^{-1}$ ) and fast (descent rates up to $4.1 \mathrm{~m} \mathrm{~s}^{-1}$ ) than in weakly stratified off-shelf waters occupied during spring, defining dives as excursions below tag-derived estimates of the surface isothermal layer depth (ILD). The duration and depth of dives also decreased significantly in association with changing water column structure, from medians in off-shelf waters during April of $0.45 \mathrm{~h}$ and $77.0 \mathrm{~m}$, respectively, to $0.16 \mathrm{~h}$ and $24.9 \mathrm{~m}$ in August. Analyses of tag measurements of internal body temperature and feeding proxies suggest that both the horizontal movement of the fish onto the continental shelf and the dives made from the warm surface layer into colder waters at depth represent a balance between the maintenance of preferred ambient temperatures and foraging opportunities.
\end{abstract}

KEY WORDS: Atlantic bluefin tuna - Thunnus thynnus · Electronic tagging · Gulf of Maine · Diving behavior

\section{INTRODUCTION}

The Atlantic bluefin tuna Thunnus thynnus is among the largest fish species in the sea, attaining lengths in excess of $3 \mathrm{~m}$ and a body mass of up to $680 \mathrm{~kg}$. Recent age estimates using bomb radiocarbon techniques on otoliths indicate that Atlantic bluefin tuna live to over $30 \mathrm{yr}$ of age (Neilson \& Campana 2008). The historical range of bluefin tuna in the Atlantic Ocean extends from South America to Norway (NRC 1994, Mather et al. 1995). This large spatial range, from tropical to subpolar seas, is attributable in part to the species' specialized endothermic physiology (Carey \& Lawson 1973). Electronic tagging has revealed complex migratory patterns that are ontogenetic and population specific (Block et al. 1998, 2001, 2005, Lutcavage et al. 1999). Tagging, genetics, and analyses of otolith chemical markers indicate at least 2 populations overlapping on North Atlantic foraging grounds which display fidelity to known breeding areas in either the Gulf of Mexico or the Mediterranean Sea (Block et al. 2005, Carlsson et al. 2007, Boustany et al. 2008, Rooker et al. 2008).

Atlantic bluefin tuna are managed by the International Commission for the Conservation of Atlantic Tunas (ICCAT) as separate western and eastern stocks, with a management line separating the 2 stocks at the $45^{\circ} \mathrm{W}$ meridian (NRC 1994). Both populations in the North Atlantic are severely depleted (ICCAT 2007). 
The Gulf of Mexico breeding population (western stock) experienced an acute decline in the late 1960s and early 1970s. Strict quotas and a recovery plan were enacted in 1981 to stimulate stock rebuilding. To date, however, the western stock has not recovered, and current estimates of western spawning stock biomass indicate a decline of almost $90 \%$ from the virgin stock biomass pre-1950 (ICCAT 2007). Excessive over-fishing in the past 3 decades on the Mediterranean-spawned populations has also caused severe declines in the eastern stock (MacKenzie et al. 2009). Management measures are complicated by results from tagging, elemental analyses, and genetics that indicate higher levels of trans-oceanic mixing than assumed in management models and evidence of a more intricate stock structure within the Mediterranean Sea than previously thought (Block et al. 2005, Carlsson et al. 2007, Boustany et al. 2008, Rooker et al. 2008, Kurota et al. 2009).

Effective management of the Atlantic bluefin tuna fishery will require a detailed understanding of the movements and behaviors of this commercially valuable top predator. Historically, information on the distribution and movements of Atlantic bluefin tuna was derived from conventional tagging programs and fisheries catch data (NRC 1994, Mather et al. 1995). More recently, tagging with electronic devices, especially microprocessor-based data storage tags, is allowing such behaviors to be quantified at unprecedented resolution in both space and time, and for multi-year durations (Lutcavage et al. 1999, Arnold \& Dewar 2001, Gunn \& Block 2001, Block et al. 2005, Teo et al. 2007).

The continental shelf of the Gulf of Maine and Canadian Maritimes (see Fig. 1) constitutes an important foraging ground for bluefin tuna during the spring-fall period (Bigelow \& Schroeder 1953, Mather et al. 1995). The bluefin tuna display a seasonal migration, generally arriving in these shelf waters in May-June and departing by October-November (Lutcavage et al. 1999, Block et al. 2001, 2005, Stokesbury et al. 2004, Wilson et al. 2005, Boustany 2006). Historically, the New England fishery has accounted for 73 to $98 \%$ of the total annual USA commercial landings (NMFS 1995), but catches have declined substantially in the past decade (ICCAT 2007). From conventional and electronic tagging studies, as well as otolith microconstituent analyses, bluefin tuna in this region are known to be a mixture of eastern- and western-spawners (Mather et al. 1995, Block et al. 2005, Rooker et al. 2008). This mixed stock assemblage also varies in size and age, which complicates analyses of the movements and behavior of bluefin tuna in the region.

This northwestern Atlantic foraging region for the bluefin tuna is strongly linked to over-wintering grounds off North Carolina. The Carolina coastal wa- ters have been the focal point for bluefin tuna catch and release by the Tag-A-Giant electronic tagging program since 1996 (Block et al. 2001, 2005, Boustany 2006, Walli et al. 2009). The majority of fish tagged by this program off North Carolina during winter months were found the following summer off New England and, to a lesser extent, in Canadian shelf waters (Block et al. 2001, 2005, Boustany 2006, Walli et al. 2009). Electronic tagging studies conducted in the Gulf of Maine region during summer and fall have found that upon exiting the area, tagged fish often moved southwards along the continental shelf towards North Carolina (Block et al. 2001, Stokesbury et al. 2004, Wilson et al. 2005, Teo et al. 2007). Additional movements from this region into the central and eastern Atlantic and Mediterranean Sea have also have been observed, confirming this as a region of mixing (Block et al. 2005).

In addition to providing insight into horizontal movements, electronic tags have provided rich datasets for examining the vertical behaviors of bluefin tuna in relationship to oceanographic conditions. Prior studies have found that the depths occupied by bluefin tuna in the northwestern Atlantic vary with location, season, body length, time of day, and moon phase (Lutcavage et al. 2000, Wilson et al. 2005, Boustany 2006, Walli et al. 2009). Bluefin tuna in the Gulf of Maine region during spring and summer occupy shallower depths than those fish present in neighboring offshore waters during winter, which has been suggested to relate to seasonal increases in the vertical stratification of the water column (Wilson et al. 2005). A correlation has also been observed between the mean daily diving depth of tagged bluefin tuna and thermocline depth (Walli et al. 2009). Bathymetric constraints imposed by the fish moving onto the continental shelf from off-shelf regions and changes in the vertical distributions of prey may also play a role in the seasonal and spatial patterns in vertical behavior observed (Block et al. 2001, Wilson et al. 2005, Walli et al. 2009).

In highly stratified water columns at northern latitudes, Atlantic bluefin tuna spend most of their time within the warm mixed layer, but often display oscillatory diving behaviors, moving repeatedly between the mixed layer and the cooler waters below the thermocline (Carey \& Olson 1982, Lutcavage et al. 2000, Gunn \& Block 2001). This pattern (often referred to as bounce diving) has been observed in a wide range of tuna species (Holland et al. 1992, Kitagawa et al. 2001, 2004, Brill et al. 2002, Schaefer et al. 2007). By diving from the warmer surface waters to depth the tunas are presumed to gain access to prey resources found in the colder waters below the surface mixed layer, with returns to the surface hypothesized to be for re-warming (Holland et al. 1992, Kitagawa et al. 2001, 2004). A cold-induced slowing of the heart rate (i.e. bradycar- 
dia) has been observed in laboratory studies of Pacific bluefin tuna Thunnus orientalis, and the re-warming during surface intervals between dives is likely necessary for re-oxygenation of cardiac and swimming muscle tissues (Blank et al. 2004).

Measurements of visceral temperature made by implanted archival tags have been used to study the feeding biology of bluefin tunas. Heat associated with the metabolic processes of digestion results in a measurable warming of the visceral cavity of bluefin tuna, referred to as the heat increment of feeding (Carey et al. 1984, Kitagawa et al. 2004, Walli 2007, Bestley et al. 2008). Such warming in juvenile bluefin tuna visceral cavity temperature is often preceded by a rapid drop in temperature, likely related to the ingestion of prey and/or ambient seawater. In juvenile Southern (Thunnus maccoyii) and Pacific bluefin tuna, stereotypical patterns of warming and cooling of visceral temperature measured by internal tags have been used to identify feeding events, and in some cases to estimate the number of calories ingested, the food source, and the size of the meal (Gunn et al. 2001, Kitagawa et al. 2004, Walli 2007, Bestley et al. 2008). In adult and adolescent Atlantic bluefin tuna, such detection of feeding events is complicated by the thermal inertia of the fish: the large body mass dampens the temperature signal associated with the heat increment of feeding (Carey et al. 1984, Walli 2007). In addition, bluefin tuna body temperature is a function of metabolic heat production (inclusive of the heat increment of feeding and muscular activity) and of conductive and convective heat transfers to the environment, and thereby of ambient water temperature (Brill et al. 1994). Bluefin tuna in the northwestern Atlantic experience strong variability in ambient temperature due to the highly stratified waters of their habitat, coupled with their repetitive and rapid diving behaviors. These factors make the unambiguous assignment of fluctuations in body temperature to feeding events more challenging than for the juvenile bluefin tunas studied previously, but tag measurements of body temperature nonetheless offer a powerful tool for studying feeding in Atlantic bluefin tuna.

In this study we examine detailed time-series data from implanted archival tags and externally attached pop-up satellite archival tags to study the movements and behaviors of Atlantic bluefin tuna in the northwestern Atlantic (inclusive of the Gulf Stream, the Gulf of Maine, and Canadian shelf waters; see Fig. 1). In particular, we examine the horizontal movements and diving behaviors of bluefin tuna in this time and region in relation to oceanographic conditions, especially ambient temperature and the stratification of the water column. We also present preliminary analyses of tag measurements of body temperature as a proxy for feeding.

\section{MATERIALS AND METHODS}

Tagging protocol. The focus of this study was an examination of high-resolution time-series records available from electronic tags deployed by the Tag-AGiant program where the tagged fish showed visitation of our northwestern Atlantic study region (see Fig. 1). Tags for this analysis were from deployments on Atlantic bluefin tuna captured in offshore waters in the vicinity of Cape Lookout (near $34.5^{\circ} \mathrm{N}, 76^{\circ} \mathrm{W}$ ), North Carolina, during the months of January and February of 1999 to 2004 (see Table 1). Full details on all tags deployed over the course of the program are provided elsewhere (Block et al. 1998, 2005, Boustany 2006, Teo et al. 2007, Walli et al. 2009).

Atlantic bluefin tuna were caught by rod and reel and brought on-board the tagging vessel via a custom-built aluminum ramp at the base of a transom door. A stainless steel or titanium lip hook was carefully placed in the most rostral position in the lower jaw and used to pull the fish from the water onto a wet vinyl mat on the vessel. Once aboard the vessel, the eyes were covered with a soft blindfold soaked in fish slime replacement (PolyAqua, Novalek), and a seawater hose was used to oxygenate the gills. Fish were measured for length (curved fork length, CFL), internally and/or externally tagged, and released. Any terminal tackle was removed.

Internal archival tags (Wildlife Computers, Lotek, or Northwest Marine Technology), henceforth referred to as 'archival tags', were surgically implanted into the peritoneal cavity with the external sensor stalk protruding to the outside of the body (Block et al. 2005). In some cases, 2 sutures were used (Ethilon 4.0 metric non-absorbable black nylon monofilament with a CPX needle), first to close the incision and then to anchor the archival tag in place. In other instances, a single suture was used to close the incision in combination with a 'button' constructed from a Floy-type tag with $30 \mathrm{~kg}$ monofilament. The button was used to anchor the tag by tying it to a loop on the tag, placing it through the incision, and securing it external to the fish. Two green Floy conventional tags were always attached to the fish in the vicinity of the second dorsal fin to alert fishers to the presence of the internal archival tag and the reward program.

Pop-up Archival Transmitting tags (Wildlife Computers), henceforth referred to as ' $\mathrm{PAT}^{\prime}$ ' were attached to the fish using titanium darts (head size $6 \mathrm{~mm} \times$ $1 \mathrm{~mm}$ ) and shrink-wrap covered $130 \mathrm{~kg}$ monofilament leaders to prevent abrasion. Through the years a number of methods were used to extend the duration the PAT tags remained on the fish, including the use of one or 2 'loops' intended to prevent the tags from excessive motion. The loops were constructed with Floy-type tags with standard nylon heads and 30 or $40 \mathrm{~kg}$ mono- 
filament line, fashioned by bringing the ends of the shrink-wrapped portion of the Floy tag together and then using bait twine or 3 layers of waxed dental floss to secure the loop closed. The floss regions were always covered with 3 layers of marine epoxy prior to putting the loops around the PAT tags. The result was a securing of the PAT tag to the fish near the ground ring, with enough looseness to allow the tag to slide out once the monel detachment pin had corroded. The PAT tags analyzed in the present study were programmed to release from the fish 6 to 12 months after deployment. From 2002 onwards, all PAT tags were equipped with premature release detection software.

The main purpose of this study was to analyze bluefin tuna diving behavior in relation to water column structure based on time series of depth and temperature measurements. Thus, we focused only on recovered tags returned through the reward program (archival or PAT) for which an archival time series of at least 3 mo duration was obtained. The tags considered here measured ambient light level, pressure, and ambient temperature at 1 or 2 min intervals. Archival tags additionally measured the internal temperature of the peritoneal cavity, henceforth referred to as 'body temperature.' Tag technology and sensor resolution evolved over the course of the research program. Archival tags examined in the present study were either Wildlife Computers Mk7 tags (deployed from 1996 to 1999) or Lotek LTD2310 tags (deployed from 2002 to 2008). The Mk7 tags sampled temperature at a resolution of $0.1^{\circ} \mathrm{C}$ for temperatures between 12 and $26.95^{\circ} \mathrm{C}$ and a resolution of $0.2^{\circ} \mathrm{C}$ for temperatures higher or lower than this range, and sampled depth with resolutions of $1,2,4,8$, and $16 \mathrm{~m}$ for depth ranges of -20 to $99.5,100$ to $199.5,200$ to $299.5,300$ to 499.5 , and 500 to $979.5 \mathrm{~m}$, respectively. LTD2310 tags recorded temperature with a resolution of $0.05^{\circ} \mathrm{C}$ and accuracy of $\pm 0.1^{\circ} \mathrm{C}$ for temperatures from 0 to $30^{\circ} \mathrm{C}$, and depth with a resolution of $1 \mathrm{~m}$. Northwest Marine Technology tags were also deployed (1999 to 2002), but these logged the timeseries data necessary for the dive and other analyses described below for only the first $2 \mathrm{mo}$, and so were not included for analysis. PAT tags analyzed in the present study were Wildlife Computers hardware versions 2.0 through 4.0 , with temperature measured at $0.05^{\circ} \mathrm{C}$ resolution with an accuracy of $\pm 0.1^{\circ} \mathrm{C}$ and depth sampled at $0.5 \mathrm{~m}$ resolution with an accuracy of $\pm 1 \%$ of the reading.

Study region. The focus of our analyses was on the continental shelf waters of the Gulf of Maine and Canadian Maritimes, as well as the adjacent off-shelf waters of the northern Gulf Stream (Fig. 1A). Analysis was therefore restricted to those 35 tags (21 archival and 14

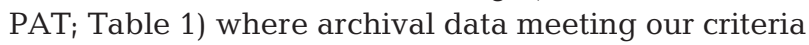
were available and where the tracks showed visitation of the region north of $38^{\circ} \mathrm{N}$, west of $53^{\circ} \mathrm{W}$, and south of $51^{\circ} \mathrm{N}$ (Table 1, Fig. 1B,C). Fish simply passing through this region en route to offshore waters of the central Atlantic (defined as fish that spent less than a month in the region and that did not move onto the continental shelf) were not included in the analysis. For some spatial analyses, the overall study region was divided into geographical sub-areas, including off-shelf waters (all waters beyond the $500 \mathrm{~m}$ isobath), the Gulf of Maine basins (waters in the Gulf deeper than $150 \mathrm{~m}$ ), the Gulf of Maine Shelf (shallower than $150 \mathrm{~m}$ ), and the Canadian Shelf (inclusive of the Scotian Shelf, Cabot Strait, and waters off southern Newfoundland) (Fig. 1A).

Geolocation estimation. The positions and tracks of tagged fish were reconstructed using light-level-based algorithms for estimating longitude (Wilson et al. 1992, Hill \& Braun 2001), and sea surface temperature (SST)and bathymetry-based algorithms for latitude (Teo et al. 2004, 2007). These algorithms are estimated to have root mean square errors of 0.78 and $0.90^{\circ}$ for longitude and latitude, respectively, when applied to data from archival tags or recovered PAT tags deployed on Atlantic bluefin tuna (Teo et al. 2004). Gaps in the track data occasionally resulted from such factors as cloud cover in the satellite observations of SST used in estimating latitude and the influence of diving on tag measurements of light levels. Missing positions were estimated via linear interpolations based on great circle distances between geolocations.

Based on daily position estimates, the fish were assigned to one of the 4 geographical sub-areas defined above on each day spent in the study region. To account for geolocation uncertainty, the maximum depth attained each day was checked for consistency with the bathymetry of the assigned sub-area. Data collected on days where the position estimate fell within the Gulf of Maine basins or Canadian Shelf subareas but where the maximum depth of the fish that day exceeded $500 \mathrm{~m}$ (a depth not consistent with being on the shelf), or where the position was in the Gulf of Maine Shelf sub-area but the maximum depth exceeded $150 \mathrm{~m}$, were not included in any spatial comparisons between sub-areas. Similarly, data collected on days with interpolated positions were not included in any spatial analyses comparing sub-areas.

Depth and temperature analysis. Drift in the pressure sensors used to measure depth was corrected for both tag types based on the assumption that the shallowest depth measured each day represented the surface. Drift in archival tag depth measurements (typically on the order of 0 to $3 \mathrm{~m}$ ) was corrected post-recovery using a third-order polynomial fit to these minimum daily depth measurements (Teo et al. 2004). PAT tag depth measurements were corrected on a daily basis using the manufacturer's software on board the tag. 
Table 1. Deployment and recapture or pop-up end-point data for the 35 analyzed tags. Tags were either surgically implanted archival tags (Wildlife Computers [WC] MK7 or Lotek 2310), or externally attached pop-up satellite archival tags (Wildlife Computers PAT). Tags were deployed on bluefin tuna Thunnus thynnus in waters offshore of Cape Lookout, North Carolina, in the vicinity of $34.5^{\circ} \mathrm{N}, 76^{\circ} \mathrm{W}$. Fish length was measured at deployment as curved fork length (CFL). End-date, -latitude and -longitude are the dates and positions of recapture (archival tags) or the tag's release from the fish (PAT tags), respectively. Days at liberty: number of days between deployment and the end-point. Days in region: total number of days spent in the northwestern Atlantic study region

\begin{tabular}{|c|c|c|c|c|c|c|c|c|}
\hline Tag type & Tag no. & $\begin{array}{l}\text { Deployment date } \\
(\mathrm{m} / \mathrm{d} / \mathrm{yr})\end{array}$ & $\begin{array}{l}\text { CFL } \\
(\mathrm{cm})\end{array}$ & $\begin{array}{l}\text { End-date } \\
(\mathrm{m} / \mathrm{d} / \mathrm{yr})\end{array}$ & $\begin{array}{l}\text { End- } \\
\text { latitude }\end{array}$ & $\begin{array}{l}\text { End- } \\
\text { longitude }\end{array}$ & $\begin{array}{l}\text { Days at } \\
\text { liberty }\end{array}$ & $\begin{array}{l}\text { Days in } \\
\text { region }\end{array}$ \\
\hline WC-Mk7 & $\begin{array}{l}98-521 \\
98-502 \\
98-507 \\
98-518 \\
98-508 \\
98-512\end{array}$ & $\begin{array}{c}1 / 1 / 1999 \\
1 / 14 / 1999 \\
1 / 16 / 1999 \\
1 / 16 / 1999 \\
1 / 17 / 1999 \\
1 / 17 / 1999\end{array}$ & $\begin{array}{l}219 \\
214 \\
217 \\
209 \\
199 \\
207\end{array}$ & $\begin{array}{c}4 / 6 / 2000 \\
4 / 26 / 2001 \\
8 / 8 / 2000 \\
8 / 30 / 2002 \\
6 / 15 / 2001 \\
8 / 22 / 2000\end{array}$ & $\begin{array}{c}37.41 \\
29.31 \\
42 \\
40.5 \\
38.89 \\
41.18\end{array}$ & $\begin{array}{c}-19.72 \\
-13.08 \\
-70 \\
-69.41 \\
15.65 \\
-69.1\end{array}$ & $\begin{array}{c}461 \\
833 \\
570 \\
1322 \\
880 \\
583\end{array}$ & $\begin{array}{c}266 \\
105 \\
99 \\
21 \\
227 \\
12\end{array}$ \\
\hline LTD2310 & $\begin{array}{l}\text { A0014 } \\
\text { A1025 } \\
\text { A0781 } \\
\text { A1005 } \\
\text { A1016 } \\
\text { A0702 } \\
\text { A0744 } \\
\text { A1000 } \\
\text { A0532 } \\
\text { A0560 } \\
\text { A1021 } \\
\text { A0902 } \\
\text { A2217 } \\
\text { A2187 } \\
\text { A2158 }\end{array}$ & $\begin{array}{c}2 / 1 / 2002 \\
1 / 13 / 2003 \\
1 / 14 / 2003 \\
1 / 18 / 2003 \\
1 / 18 / 2003 \\
1 / 18 / 2003 \\
1 / 18 / 2003 \\
1 / 21 / 2003 \\
1 / 25 / 2003 \\
1 / 25 / 2003 \\
1 / 26 / 2003 \\
1 / 26 / 2003 \\
1 / 9 / 2004 \\
1 / 14 / 2004 \\
1 / 22 / 2004\end{array}$ & $\begin{array}{l}201 \\
190 \\
213 \\
185 \\
209 \\
185 \\
207 \\
199 \\
208 \\
195 \\
190 \\
176 \\
222 \\
219 \\
180\end{array}$ & $\begin{array}{c}11 / 30 / 2004 \\
6 / 5 / 2004 \\
12 / 26 / 2004 \\
6 / 26 / 2006 \\
6 / 10 / 2006 \\
2 / 8 / 2006 \\
12 / 30 / 2004 \\
8 / 28 / 2005 \\
10 / 12 / 2005 \\
5 / 13 / 2007 \\
8 / 12 / 2005 \\
9 / 6 / 2003 \\
\text { unknown } \\
3 / 12 / 2008 \\
9 / 3 / 2005\end{array}$ & $\begin{array}{c}35.95 \\
45.37 \\
46.49 \\
35.31 \\
33.48 \\
32.63 \\
44.5 \\
41.22 \\
44.6 \\
36.15 \\
42 \\
44.59 \\
\text { unknown } \\
26.35 \\
41.16\end{array}$ & $\begin{array}{c}-5.49 \\
-30.08 \\
-39.97 \\
15.87 \\
19.93 \\
-21.22 \\
-30.28 \\
-70.72 \\
-63.06 \\
-5.91 \\
-67.88 \\
-66.47 \\
\text { unknown } \\
-94.18 \\
-70.67\end{array}$ & $\begin{array}{c}1033 \\
509 \\
712 \\
1255 \\
1239 \\
1117 \\
712 \\
950 \\
991 \\
1569 \\
929 \\
223 \\
723 \\
1519 \\
590\end{array}$ & $\begin{array}{l}186 \\
201 \\
118 \\
203 \\
148 \\
201 \\
140 \\
178 \\
194 \\
217 \\
172 \\
148 \\
205 \\
124 \\
147\end{array}$ \\
\hline WC-PAT & $\begin{array}{l}00-278 \\
00-277 \\
00-300 \\
00-679 \\
00-691 \\
00-703 \\
00-718 \\
00-272 \\
00-732 \\
00-879 \\
02-608 \\
02-633 \\
02-668 \\
03-219\end{array}$ & $\begin{array}{c}1 / 3 / 2001 \\
1 / 7 / 2001 \\
1 / 9 / 2001 \\
1 / 11 / 2001 \\
1 / 12 / 2001 \\
1 / 14 / 2001 \\
1 / 15 / 2001 \\
1 / 19 / 2001 \\
1 / 12 / 2002 \\
1 / 17 / 2002 \\
1 / 10 / 2003 \\
1 / 16 / 2003 \\
1 / 25 / 2003 \\
1 / 22 / 2004\end{array}$ & $\begin{array}{l}218 \\
227 \\
214 \\
197 \\
222 \\
216 \\
190 \\
215 \\
206 \\
199 \\
211 \\
207 \\
215 \\
240\end{array}$ & $\begin{array}{c}8 / 1 / 2001 \\
8 / 1 / 2001 \\
8 / 1 / 2001 \\
7 / 1 / 2001 \\
7 / 15 / 2001 \\
6 / 29 / 2001 \\
7 / 6 / 2001 \\
8 / 12 / 2001 \\
9 / 20 / 2002^{\mathrm{a}} \\
6 / 10 / 2002 \\
6 / 17 / 2003^{\mathrm{a}} \\
8 / 7 / 2003 \\
9 / 16 / 2003 \\
10 / 12 / 2004^{\mathrm{a}}\end{array}$ & $\begin{array}{c}\text { unknown } \\
42.32 \\
43.31 \\
42.69 \\
44.1 \\
38.85 \\
40.12 \\
44.46 \\
58.55 \\
41.36 \\
40 \\
43.49 \\
44.95 \\
41.16\end{array}$ & $\begin{array}{c}\text { unknown } \\
-68.58 \\
-70.15 \\
-61.99 \\
-67.28 \\
-70.4 \\
-68.15 \\
-67.15 \\
-21.3 \\
-69.61 \\
-67.5 \\
-68.82 \\
-65.84 \\
-70.67\end{array}$ & $\begin{array}{l}210 \\
206 \\
204 \\
171 \\
184 \\
166 \\
172 \\
205 \\
251 \\
144 \\
158 \\
203 \\
234 \\
264\end{array}$ & $\begin{array}{c}99 \\
63 \\
76 \\
15 \\
36 \\
28 \\
40 \\
67 \\
19 \\
34 \\
40 \\
79 \\
125 \\
130\end{array}$ \\
\hline
\end{tabular}

Water temperature and depth utilizations of the tuna were quantified by calculating daily values of various quantities from the tags' time-series measurements, for all days that each fish spent in the study region. Daily frequency distributions of depths occupied were calculated in $10 \mathrm{~m}$ bins. Daily mean SST was calculated by averaging all temperature measurements made at depths shallower than $5 \mathrm{~m}$. The daily mean was also calculated for tag measurements of ambient water temperature, as well as for internal body temperature for the 21 archival tags where measurements of body temperature were available (Table 1). Thermal excess was calculated for each point in the raw time-series data as body temperature minus ambient water temperature. Daily minima, maxima, and means were then calculated from the resulting thermal-excess time series.
To supplement tag measurements of SST at times when the bluefin tuna were not present in the study region, ancillary data on SST were obtained from buoys maintained by the National Buoy Data Center (www.ndbc. noaa.gov) at one on-shelf location on Georges Bank and one off-shelf location south of Georges Bank (buoys 44011 and 44004, respectively; Fig. 1A).

Water column analysis. The water column inhabited by the bluefin tuna was characterized by deriving profiles of temperature in $10 \mathrm{~m}$ depth intervals based on locally weighted polynomial regression fits to depthtemperature time-series records every $6 \mathrm{~h}$. The surface iso-thermal layer depth (ILD) was then identified from these profiles following the method of Kara et al. (2000), wherein a threshold temperature change $\Delta T$ is defined (in this case $0.8^{\circ} \mathrm{C}$ ) and the temperature-depth profile is 

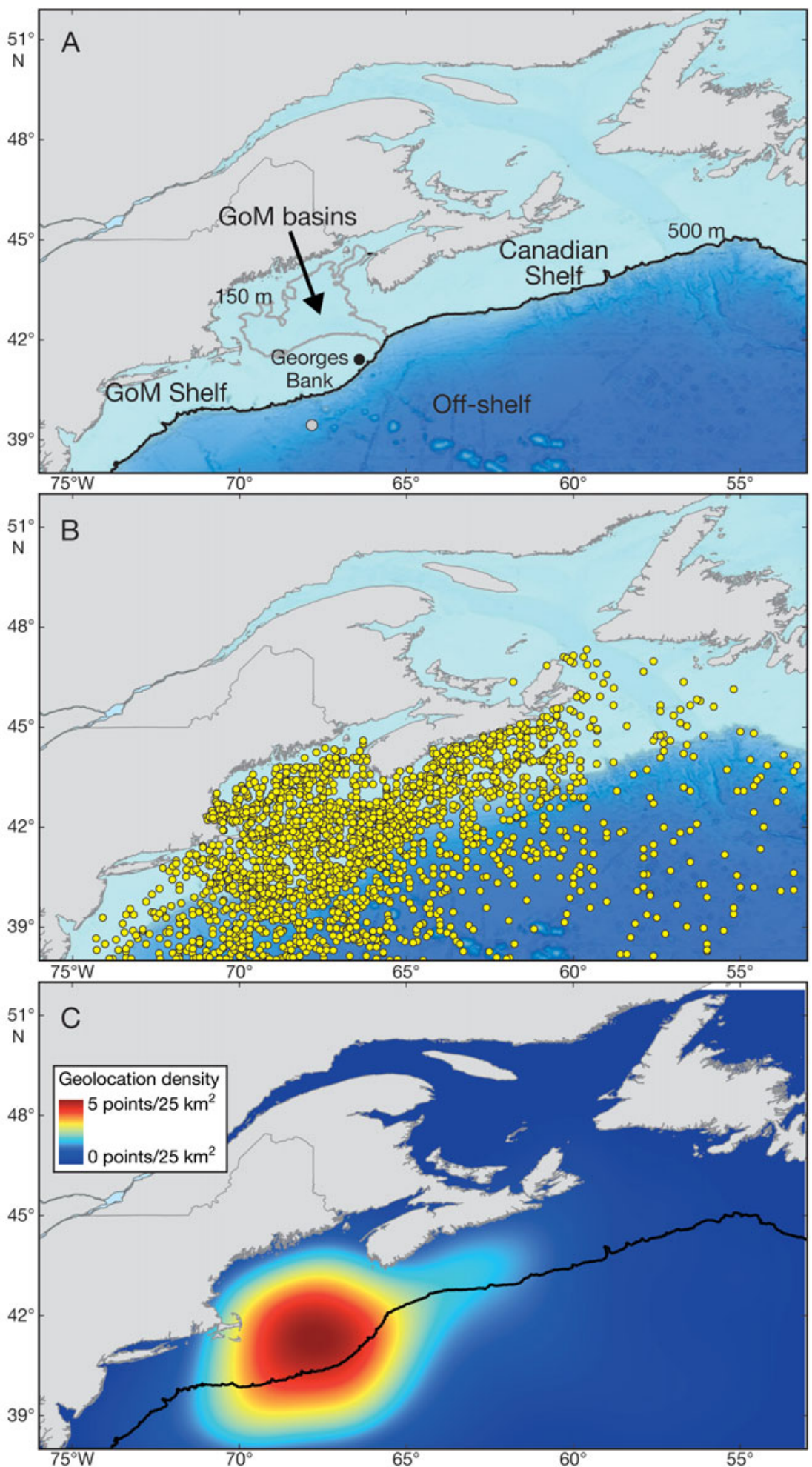

Fig. 1. (A) Study region, encompassing the continental shelf and off-shelf waters of New England and the Canadian Maritimes, divided into 4 sub-areas denoted via the black and gray lines. Off-shelf = waters beyond the $500 \mathrm{~m}$ isobath (black line). Gulf of Maine (GoM) was divided into shelf $(<150 \mathrm{~m}$; gray line) and basin (>150 m) components. Canadian Shelf included the Scotian Shelf, Cabot Strait, and waters off southern Newfoundland. Dots indicate the location of buoys (offshelf: gray, on-shelf: black) maintained by the National Oceanic and Atmospheric Administration from which ancillary data on sea surface temperature were obtained. (B) Daily position estimates made within the study region for all 35 fish examined in this study. (C) Kernel density map showing the smoothed density of these positions per $25 \mathrm{~km}^{2}$

$10 \mathrm{~m}$ if no such constant temperature region is found. Kara et al. (2000) tested the results of this algorithm for $\Delta T=0.8^{\circ} \mathrm{C}$ against World Ocean Circulation Experiment data collected in the North Pacific, and found that estimates of ILD closely approximated mixed layer depth. In addition to ILD, the structure of the water column was also quantified via an index of the vertical temperature gradient, defined as the temperature difference between 10 and $100 \mathrm{~m}$ in depth from each $6 \mathrm{~h}$ profile.

Dive analysis. In order to analyze quantitatively the diving behavior of bluefin tuna, a method was developed for identifying individual dives in the depth time-series data. Previous studies of Pacific bluefin tuna have defined dives heuristically as starting when a given fish's depth exceeded a threshold depth of $10 \mathrm{~m}$ and ending when the fish returned above this depth (Kitagawa et al. 2004, 2007). Examining depth timeseries data for Atlantic bluefin tuna collected by both archival (e.g. Gunn \& Block 2001, Block et al. 2001) and sound-emitting 'acoustic' tags used for short-term tracking studies (e.g. Carey \& Olson 1982, Lutcavage et al. 2000), however, it is evident that the shallow

examined for a region of constant temperature, defined as variations between successive depth measurements of less than $\Delta T / 10$. The ILD is taken as the point at which temperature changes by more than $\Delta T$ relative to the constant temperature region, or relative to a depth of depth to which the fish return between dives varies in time and space, and that no single dive depth threshold (e.g. $10 \mathrm{~m}$ ) is likely to capture all dives while also avoiding the identification of putative dives that may in reality be part of between-dive surface intervals. It is 
also evident, though, that the Atlantic bluefin tuna make distinct vertical movements from within the surface iso-thermal layer to deeper depths and back (as noted by Gunn \& Block 2001, Brill et al. 2002).

Given our interest in the behavior of bluefin tuna in relationship to oceanographic conditions and the structure of the water column, here we define dives as return excursions from the surface iso-thermal layer. The start of an individual dive was identified from the tags' time-series measurements of depth by the downwards movement of a fish beyond the ILD (estimated as described above for the $6 \mathrm{~h}$ interval during which the dive started), and the dive's end as a return above the ILD. This then allowed various dive metrics to be quantified, including dive duration and the mean depth occupied during each dive. Maximum descent rate was calculated from the rate of change of depth with time over all successive depth measurements during the portion at the start of the dive where depth was monotonically increasing (i.e. from dive initiation to the first inflection point back up towards shallower depths). Ascent rate was similarly calculated, but showed similar patterns to descent rate and so is not considered further. Dive frequency was calculated as the number of dives per day and per hour. These quantities were calculated for all dives and all days that each fish spent within the study region.

Feeding analysis. A visual method was employed to identify body temperature warming events likely associated with the heat increment of feeding. Archival tag time-series measurements of body temperature, ambient temperature, and depth were examined over $72 \mathrm{~h}$ windows. Feeding-related warming events were identified based on previous observations of captive archival-tagged Pacific bluefin tuna fed meals of known caloric content at known times (Walli 2007). A putative feeding event was defined as a steady rise in body temperature followed by a steady decline that could not be attributed to a concomitant decrease in ambient water temperature (e.g. at a time when ambient temperature remained constant). For this first analysis of adolescent and mature Atlantic bluefin tuna, we focused on identifying events during the month of August when the fish were mostly over the continental shelf where the difference between body and ambient temperature was large and the heat increment associated with feeding was especially pronounced and recognizable. Due to the strongly confounding influence of variability in ambient water temperature on body temperature, we were not able to automate this process in the manner of Kitagawa et al. (2004) or Walli (2007), and instead focused on manually identifying a limited number of events $(n=46)$ that we could be confident were associated with feeding, rather than other sources of variation in body tempera- ture (see 'Results' and 'Discussion' for additional details). The resulting small dataset allows an examination of the time of day at which warming events associated with putative feeding occurred, and the characteristics of dives associated with the events.

Statistical analysis. Differences in distributions of depths occupied, dive characteristics, and environmental properties were assessed between times and sub-areas within the study region using Kruskal-Wallis (K-W) non-parametric 1-way ANOVA (Siegel \& Castellan 1988). Post-hoc comparisons between groups (e.g. between months or sub-areas) were conducted using Tukey's honestly significant difference criterion, with Bonferroni adjustments to account for multiple comparisons. Correlations between dive characteristics and environmental properties, and between bluefin tuna body temperature and ambient temperature, were tested using Spearman's non-parametric rank correlation coefficient (Siegel \& Castellan 1988). Wilcoxon rank sum tests (a non-parametric equivalent to a $t$-test that compares the medians of 2 distributions) were used in examining the characteristics of dives associated with feeding events (Siegel \& Castellan 1988). Non-parametric analyses were employed due to the relevant variables not being normally distributed.

\section{RESULTS}

\section{Horizontal movement patterns}

The archival time-series data were analyzed for 35 tagged bluefin tuna that visited the study region from 1999 to 2005, for a total of 4163 d (Table 1). Curved fork lengths measured at the time of tagging ranged from 176 to $240 \mathrm{~cm}$. The tagged bluefin tuna examined in the present study arrived in the study region in spring, and occupied significantly more northern latitudes as the months progressed from spring to summer (K-W $\chi^{2}=1285, \mathrm{p}<0.0001$; Fig. 2). During this April through September time period, the SSTs occupied by the fish remained relatively constant (median tag-measured SST varying from 16.1 to $19.0^{\circ} \mathrm{C}$; Fig. 2). The variability in tag-measured SSTs was greatest during AprilJune (monthly SD ranging from 3.9 to $4.6^{\circ} \mathrm{C}_{i}$ Fig. 2), and decreased markedly during July-November (monthly SD ranging from 2.2 to $2.9^{\circ} \mathrm{C}$ ).

The bluefin tuna initially occupied off-shelf waters in the vicinity of the north wall of the Gulf Stream (Fig. 3A, see Fig. S1A in the supplement at www. int-res.com/articles/suppl/m400p245_app.pdf for the track of an individual representative fish). In the late spring and summer months the bluefin tuna moved into the continental shelf waters of the Gulf of Maine and Canadian Shelf (Fig. 3A \& Fig. S1A in the supple- 


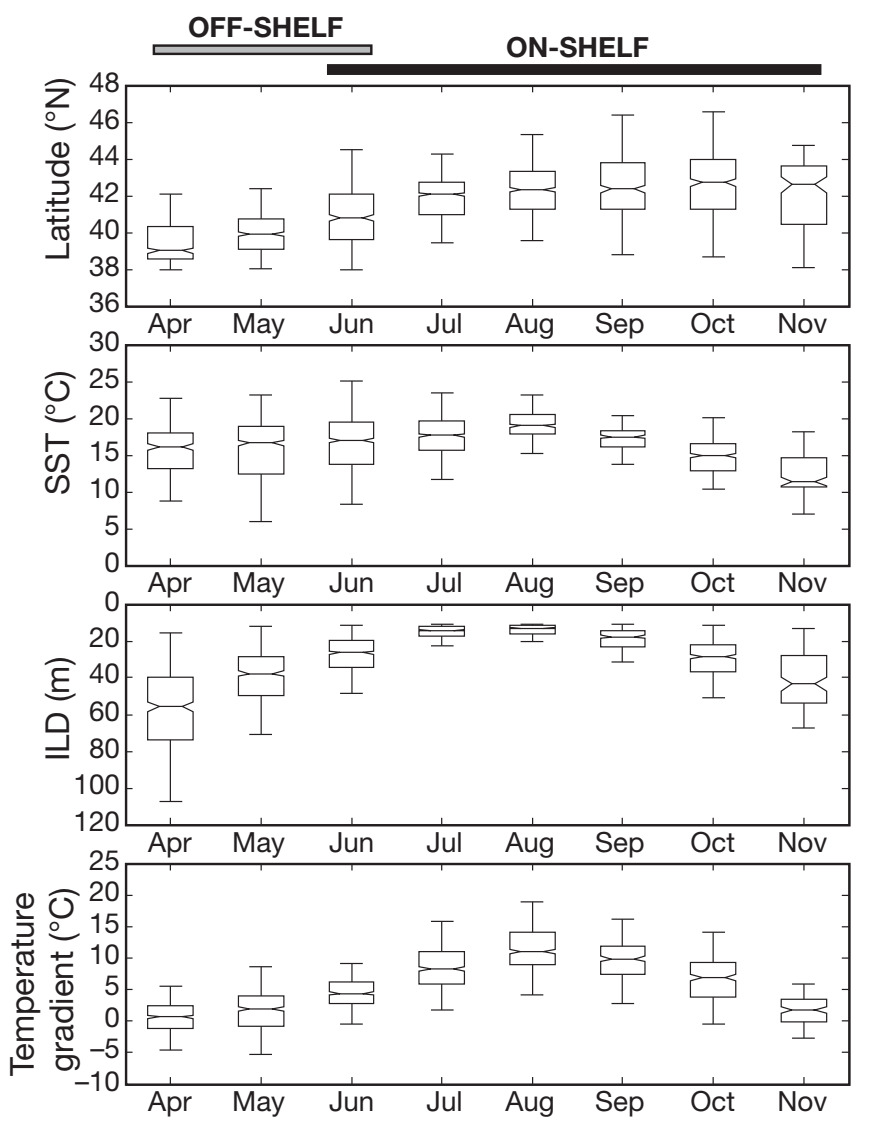

Fig. 2. Thunnus thynnus. Seasonal patterns in tag-derived estimates of environmental conditions occupied by bluefin tuna $(n=35)$. Shown are latitude, sea surface temperature (SST), iso-thermal layer depth (ILD), and temperature difference between 10 and $100 \mathrm{~m}$ in depth. Boxes: monthly medians and inter-quartile ranges calculated over the 35 fish and over all days and years spent in the study region (1999 to 2005); whiskers: the most extreme values within 1.5 times the interquartile range. All of these quantities differed significantly between months (all K-W $\chi^{2} \geq 697$, all $\mathrm{p}<0.0001$ ). The fish mostly occupied waters off the continental shelf in April-May and mostly on-shelf regions during July-November, with a transition period in June (see Fig. 3)

ment). The fish then departed the region in the late fall (Fig. 3A). Bluefin tuna spent an average \pm SD of $119 \pm$ $72 \mathrm{~d}$ of the year in the study region, with an average of $52 \pm 32 \mathrm{~d}$ spent in waters off the continental shelf and $67 \pm 48 \mathrm{~d}$ over the continental shelf. In 6 instances, data collection ended during the fish's occupancy of the region due to the fish being recaptured by the fishery, and 11 of the 14 PAT tags released while the fish was still in the study region (Table 1).

During the April to May period when the bluefin tuna were predominantly in off-shelf waters along the Gulf Stream, they occupied a relatively warm and weakly stratified water column (Fig. 2 \& Fig. S1B in the supplement). ILDs were deep (up to ca. $300 \mathrm{~m}$ ), vertical thermal gradients between 10 and $100 \mathrm{~m}$ in depth were weak, and monthly median SST as measured by the tags ranged from $16.1^{\circ} \mathrm{C}$ in April to $16.6^{\circ} \mathrm{C}$ in May (Fig. 2). Bluefin tuna showed a peak occupancy of these off-shelf waters in the month of May, when the SST measured by a remote buoy at an off-shelf location averaged over $1999-2005$ was $17.0 \pm 1.4^{\circ} \mathrm{C}$ (Fig. 3).

As temperatures measured by the off-shelf buoy warmed above $\sim 20^{\circ} \mathrm{C}$ from June onwards, the fish moved onto the continental shelf (Fig. 3B \& Fig. S1 in the supplement). Peak occupancy of on-shelf waters occurred during July, at which time median SST measured by the tags was $17.7^{\circ} \mathrm{C}$ and at the on-shelf buoy reached $15.6 \pm 0.9^{\circ} \mathrm{C}$ (Figs. $2 \& 3 \mathrm{~B}$ ). This seasonal pattern in buoy-measured SSTs was highly stable over the years of the study (Fig. 3B). Additional buoys in the study region documented similar patterns (not shown). During the summer period spent in shelf waters, the water column occupied was highly stratified, with significantly shallower ILDs (monthly median ILD during July and August of 14.3 and $13.2 \mathrm{~m}$, respectively; Fig. 2) than experienced by the fish earlier in the season in off-shelf waters (April and May median ILDs of 55.8 and $37.7 \mathrm{~m} ; \mathrm{K}-\mathrm{W} \chi^{2}=2371, \mathrm{p}<0.0001$; post-hoc tests $\mathrm{p}<0.05$; Fig. 2), while vertical thermal gradients encountered by the fish during summer were stronger $\left(\mathrm{K}-\mathrm{W} \chi^{2}=1969, \mathrm{p}<0.0001\right.$; post-hoc tests $\left.\mathrm{p}<0.05\right)$. The fish departed these continental shelf waters, and the study region as a whole, by November in association with declining SSTs (median tag-measured SST in October and November of 15.0 and $11.4^{\circ} \mathrm{C}$, respectively) (Figs. 2 \& 3).

\section{Diving behavior}

\section{Overall vertical distribution}

Within all sub-areas of the study region the bluefin tuna spent the most time in the upper $10 \mathrm{~m}$ of the water column (Fig. 4). Significantly less time was spent in the shallowest $10 \mathrm{~m}$ when the fish were in off-shelf waters ( $48 \%$ of time) than when in the on-shelf sub-areas $(62$ to $65 \%$; post-hoc tests to Kruskal-Wallis non-parametric 1-way ANOVA comparing the off-shelf waters to each on-shelf sub-area all $p<0.05)$. In off-shelf waters the bluefin tuna frequently occupied depths of up to $170 \mathrm{~m}$, with occasional dives as deep as $1015 \mathrm{~m}$. Occupancy of deeper depths was limited in on-shelf areas due to bathymetry (Fig. 4).

\section{Seasonal variability in diving behavior}

Distinct patterns in diving behavior were evident seasonally and in the different areas within the study 

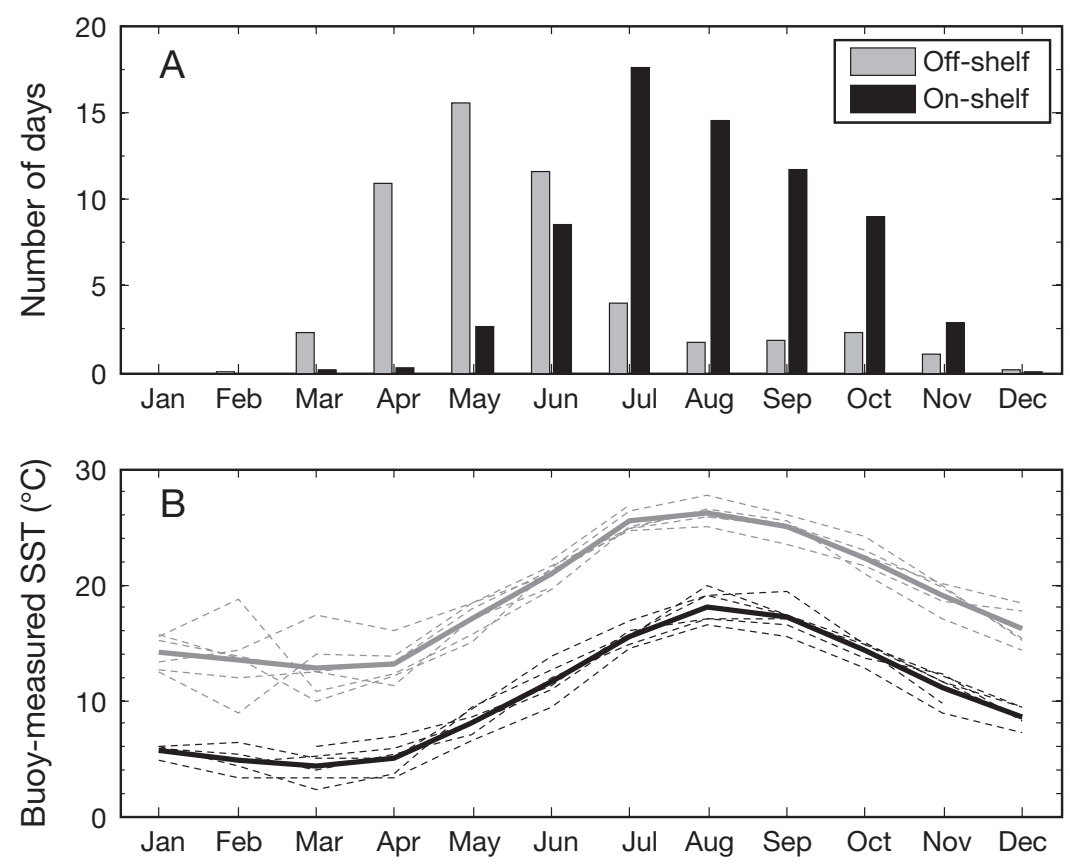

Fig. 3. Thunnus thynnus. (A) Mean number of days (averaged over all 35 fish) spent each month in the off-shelf waters of the study region (gray bars) and over the continental shelf (black bars). (B) Mean monthly sea surface temperature (SST) measured by buoys at an off-shelf location south of Georges Bank (gray solid line) and an on-shelf location over Georges Bank (black solid line; see Fig. 1 for exact buoy locations). Averages were calculated over all SST measurements made during each month and over the years 1999 to 2005 when the tunas were present in the study region. Dotted lines show monthly average SST for each of these years, and demonstrate the inter-annual stability in this seasonal temperature cycle
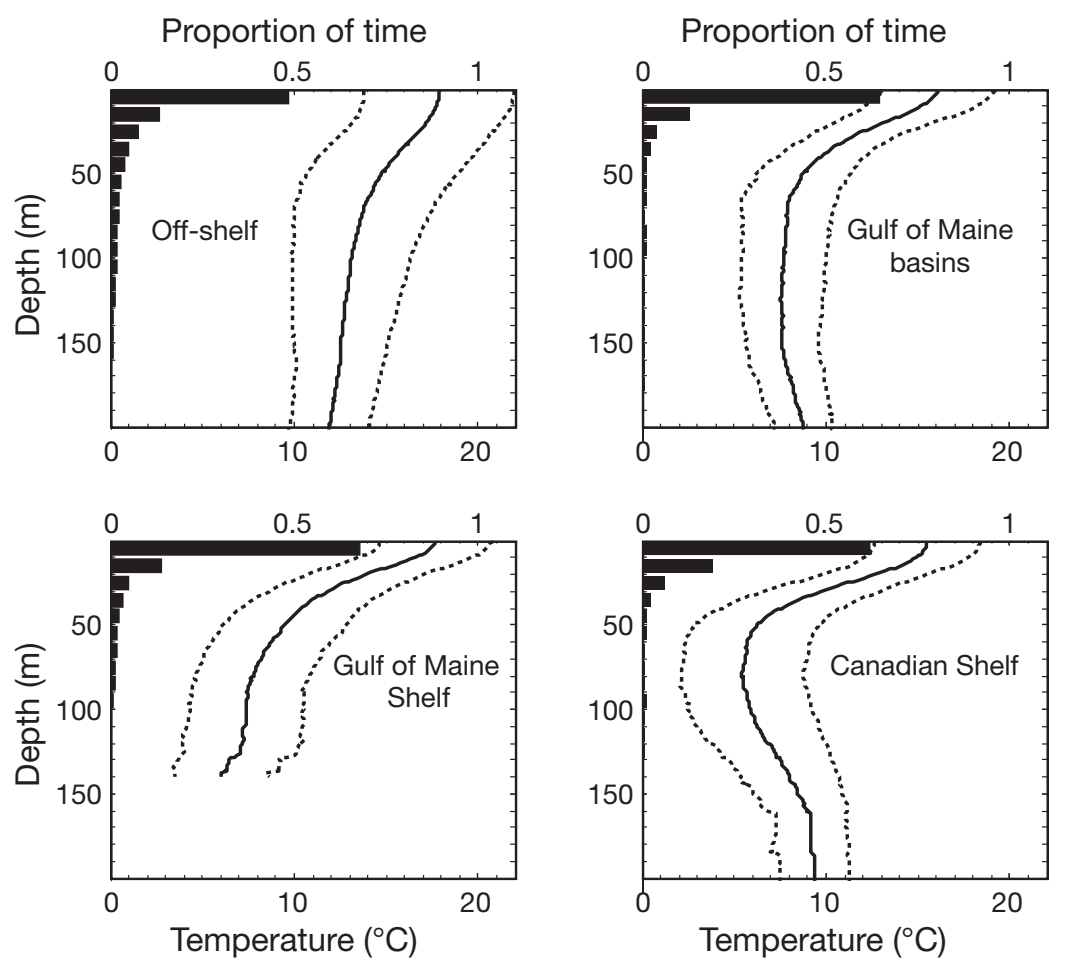

region. In the warm and weakly stratified water columns of the off-shelf region, the bluefin tunas typically exhibited the deepest dives in association with sunrise and sunset, and otherwise had an irregular diving pattern, often spending prolonged periods of time at depth (e.g. Fig. S2A in the supplement at www.int-res.com/articles/suppl/ m400p245_app.pdf). Overall, the number of dives per day was low in off-shelf waters and increased significantly as the fish moved onto the shelf $\left(\mathrm{K}-\mathrm{W} \chi^{2}=\right.$ $800, \mathrm{p}<0.0001$ ), from a median of 12 dives $\mathrm{d}^{-1}$ in April to a peak of 40 dives $\mathrm{d}^{-1}$ in August (post-hoc tests of August dive frequency vs. other months all $\mathrm{p}<$ 0.05 , other than vs. September where p > 0.05) (Fig. 5 \& Fig. S2B in the supplement). Associated with this shift from off- to on-shelf regions, dive depth also became significantly shallower (K-W $\left.\chi^{2}=1385, \mathrm{p}<0.0001\right)$, with monthly median depths varying from $77.0 \mathrm{~m}$ in April to a minimum of $24.8 \mathrm{~m}$ in August (post-hoc tests all $\mathrm{p}<0.05$, other than vs. September where $\mathrm{p}>0.05)$. While on the shelf, dives often appeared to be constrained in depth by bathymetry and potentially were associated with the ocean floor (e.g. Fig. S2B in the supplement). Dive duration also became significantly shorter over this time period $\left(\mathrm{K}-\mathrm{W} \chi^{2}=902, \mathrm{p}<0.0001\right)$, from a median of $0.45 \mathrm{~h}$ in April to medians of 0.13 to $0.16 \mathrm{~h}$ in August-November. Maximum descent rates during dives became significantly more rapid (K-W $\chi^{2}=241, \mathrm{p}<0.0001$; Fig. 5), increasing

Fig. 4. Thunnus thynnus. Bars: depth distributions of the bluefin tuna in the 4 sub-areas of the study region (averaged over all fish, years, and days spent in each sub-area between April and November), plotted as proportion of time (upper $x$-axis) spent in $10 \mathrm{~m}$ bins. Tails of the distributions extended at very low proportions to the tags' limit of 1000 $\mathrm{m}$, but are truncated here for ease of presentation. Lines: mean temperature-depth profiles (temperature on lower $x$-axis), averaged over all fish, years, and days spent in each sub-area. Dotted lines: \pm SD. Proportion of time spent in the upper $10 \mathrm{~m}$ of the water column was significantly smaller in the offshelf relative to other sub-areas (see 'Overall vertical distribution' section) 

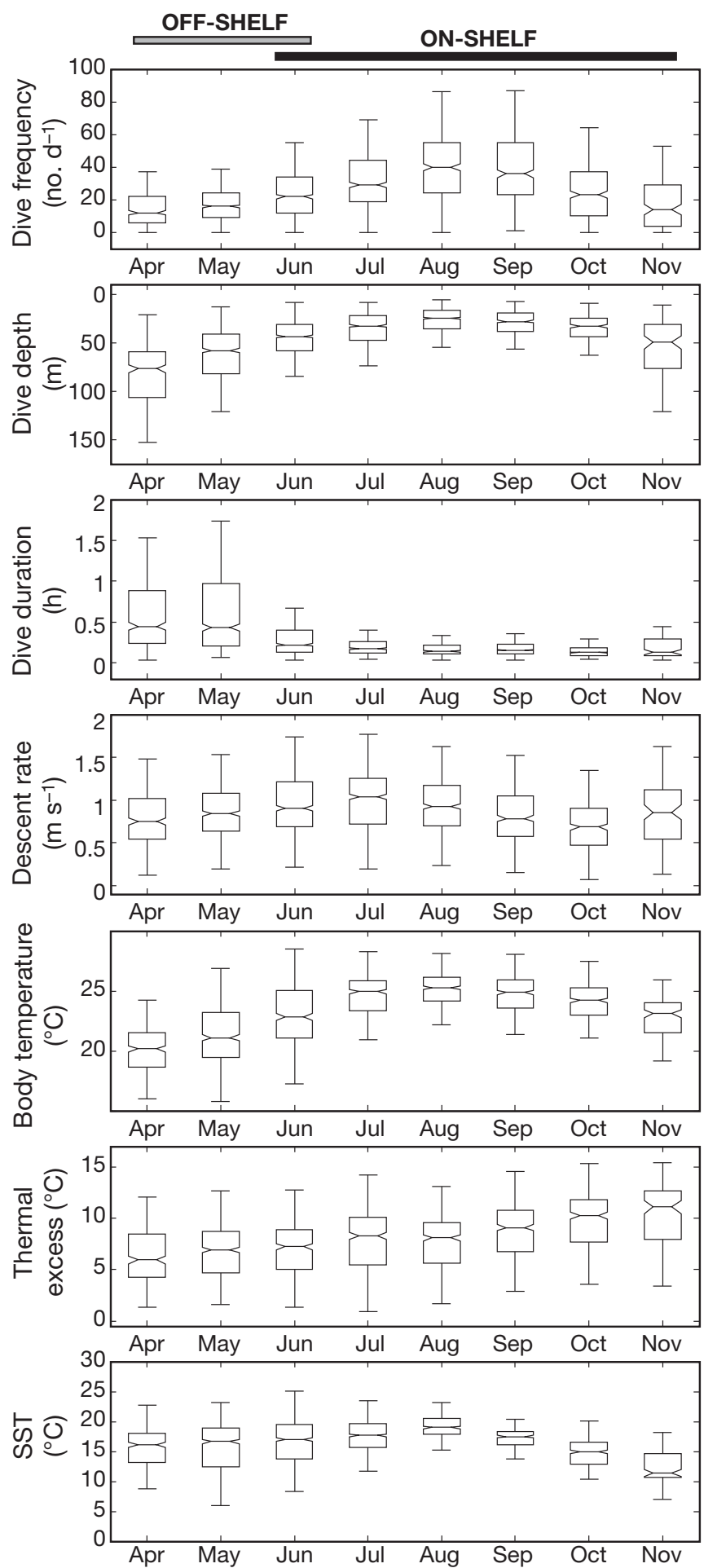

to a median of $1.03 \mathrm{~m} \mathrm{~s}^{-1}$ during July from medians of 0.75 to $0.9 \mathrm{~m} \mathrm{~s}^{-1}$ during April through May (post-hoc tests of July descent rates vs. other months all $\mathrm{p}<0.05$ ). Minimum temperatures experienced during dives averaged $8.9 \pm 4.0^{\circ} \mathrm{C}$ when the fish were in the offshelf region, and $5.7 \pm 2.8^{\circ} \mathrm{C}$ when over the shelf.
Fig. 5. Thunnus thynnus. Seasonal patterns in dive characteristics for all 35 bluefin tuna and in thermal biology for 21 fish where archival tag measurements of internal body temperature were available (Table 1). Shown are dive frequency, mean depth during dives, dive duration, maximum dive descent rate, body temperature, and thermal excess (body temperature ambient temperature) relative to month. Sea surface temperature (SST) is shown for comparison. Boxes: monthly medians and inter-quartile ranges calculated over all 21 or 35 fish studied and over all days and years spent in the study region (1999 to 2005). Whiskers: the most extreme values within 1.5 times the inter-quartile range. All of these quantities differed significantly between months (all K-W $\chi^{2} \geq 363$, all $\mathrm{p}<0.0001$ )

Diving behavior relative to oceanographic features

Dive characteristics were strongly correlated with the vertical temperature structure of the water column. In the water columns of slight or negative temperature gradients typical of the off-shelf region, daily dive frequency was low $\left(<80\right.$ dives $\left.\mathrm{d}^{-1}\right)$. Dive frequency was particularly reduced $\left(<40\right.$ dives $\left.\mathrm{d}^{-1}\right)$ in waters where SST was also cold $\left(<14^{\circ} \mathrm{C}\right)$ and ILD was deep (>100 m) (Fig. 6A,B, Table 2). In contrast, in the shallow ILDs and steep vertical temperature gradients that characterized on-shelf waters, the number of dives was highly variable, ranging from 0 to 180 dives $\mathrm{d}^{-1}$ (Figs. 5 \& $6 \mathrm{~A}, \mathrm{~B}$, see Fig. $\mathrm{S} 3$ in the supplement at www.intres.com/articles/suppl/m400p245_app.pdf). The daily mean depth occupied during dives likewise showed a strong relationship with water column structure, increasing with ILD (Spearman's rank correlation coefficient $\rho=0.64$ ) and decreasing with the temperature gradient ( $\rho=-0.65$; Fig. $6 C, D$, Table 2). Mean dive durations ranged from $2 \mathrm{~min}$ to $49 \mathrm{~h}$ and showed less of an association with ILD ( $\rho=0.32)$, but decreased with temperature gradient ( $\rho=-0.51$, Fig. $6 \mathrm{E}, \mathrm{F}$, Table 2 ). Notably, in waters where SST was particularly cold $\left(<15^{\circ} \mathrm{C}\right)$ and colder near the surface than at depth (i.e. a negative temperature gradient as in Fig. 6F), dives were substantially longer (median $1.14 \mathrm{~h}$ ) than in regions where SST was warmer than at depth (median $0.21 \mathrm{~h}$ ). Daily maximum descent rates attained during dives showed little association with the temperature gradient, but the fastest descent rates (to a maximum of $4.1 \mathrm{~m} \mathrm{~s}^{-1}$ ) were evident where ILD was shallowest (Fig. 6G,H, Table 2).

\section{Diel and spatial variability in diving behavior}

Dive frequency varied significantly over the course of the day in all sub-areas (all K-W $\chi^{2} \geq 284$, all $\mathrm{p}<$ 0.0001), with more dives during daytime hours (ca. 05:00 to $17: 00 \mathrm{~h}$ ) than at night (Fig. 7A). This decrease 

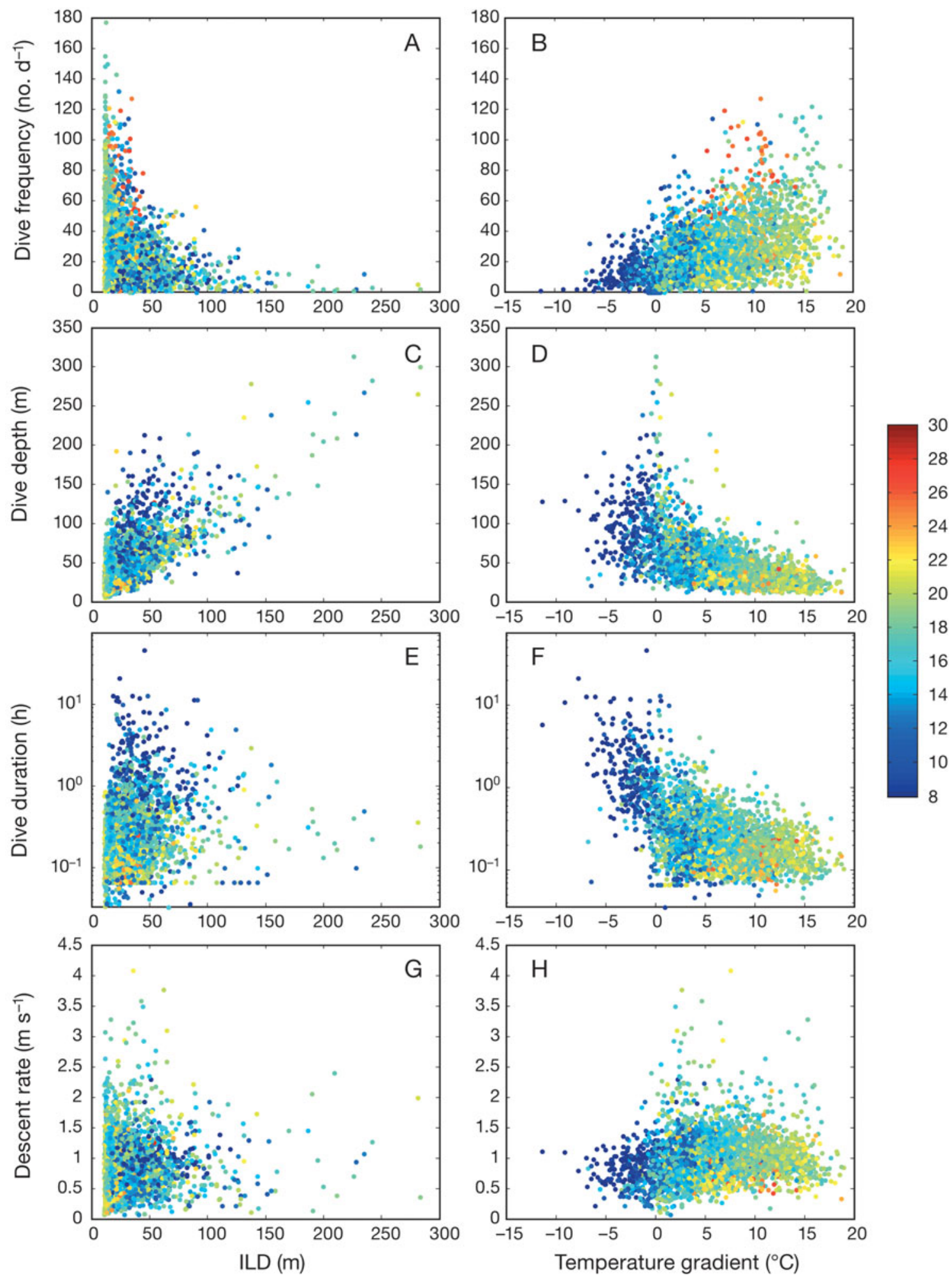

Fig. 6. Thunnus thynnus. Dive characteristics relative to the thermal structure of the water colum. Shown are dive frequency, daily mean dive depth, daily mean dive duration, and daily maximum descent rate (for all 35 fish, years, and days spent in the region during April-November), plotted relative to the corresponding iso-thermal layer depth (ILD) estimate (left-hand plots) and temperature gradient (right-hand plots). Temperature gradient is the difference in temperature between 10 and $100 \mathrm{~m}$ depth. Negative values thus indicate water columns where temperatures at the surface were colder than at depth. Dot color indicates sea surface temperature (SST); Fig. S3 in the supplement at www,int-res.com/articles/suppl/m400p245_app.pdf shows these data with dot color indicating month. See Table 2 for correlation coefficients 
Table 2. Spearman's rank correlation coefficients $(\rho)$ for correlations between dive metrics and environmental properties. All correlations were significant ( $p \leq 0.01)$, ${ }^{n s}$ except the correlation between sea surface temperature (SST) and descent rate. ILD: iso-thermal layer depth

\begin{tabular}{|c|c|c|c|c|c|c|c|}
\hline & $\begin{array}{c}\text { Dive } \\
\text { frequency }\end{array}$ & $\begin{array}{l}\text { Dive } \\
\text { depth }\end{array}$ & $\begin{array}{c}\text { Dive } \\
\text { duration }\end{array}$ & $\begin{array}{l}\text { Descent } \\
\text { rate }\end{array}$ & Latitude & SST & ILD \\
\hline Dive frequency & - & & & & & & \\
\hline Dive depth & -0.51 & - & & & & & \\
\hline Dive duration & -0.38 & 0.64 & - & & & & \\
\hline Descent rate & 0.20 & 0.08 & -0.05 & - & & & \\
\hline Latitude & 0.23 & -0.27 & -0.20 & 0.14 & - & & \\
\hline $\mathrm{SST}$ & 0.16 & -0.38 & -0.34 & $0.00^{\mathrm{ns}}$ & -0.22 & - & \\
\hline ILD & -0.46 & 0.64 & 0.32 & -0.25 & -0.46 & -0.27 & - \\
\hline Temp. gradient & 0.49 & -0.65 & -0.51 & 0.22 & 0.33 & 0.56 & -0.75 \\
\hline
\end{tabular}
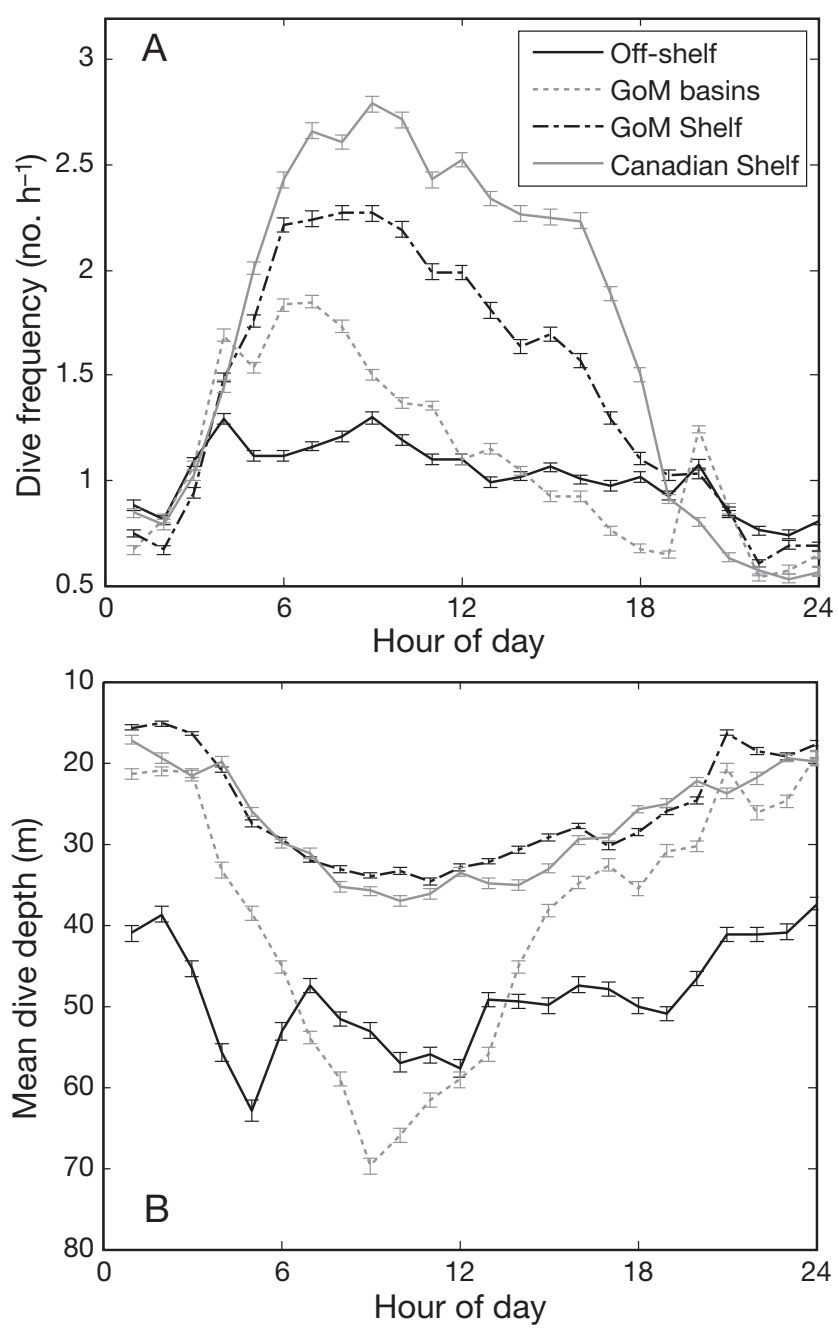

Fig. 7. Thunnus thynnus. (A) Mean dive frequency, and (B) mean dive depth relative to hour of day and region, averaged over all 35 fish, years, and days spent in each sub-area between April and November. Error bars: \pm SE. Each point represents all dives made within the hour before the point. GoM: Gulf of Maine in dive frequency from day to night was smallest in the off-shelf waters, and was significant in all sub-areas (post-hoc tests $\mathrm{p}<0.05)$. In the on-shelf sub-areas, dive frequency additionally showed an increase and then a decrease over the course of the day (post-hoc tests p < 0.05) (Fig. 7A). Daytime dive frequency was maximal in the Canadian shelf subarea, decreased on the Gulf of Maine shelf and Gulf of Maine basins, and was lowest off-shelf in the Gulf Stream and bordering waters (Fig. 7A). Some previous studies of bluefin tuna vertical distribution have observed an effect of moon phase on depths occupied (e.g. Wilson et al. 2005, Kitagawa et al. 2007); any such lunar effect on diving behavior was ignored here, which may introduce some uncertainty into the day-night and regional patterns observed.

Associated with the diel change in dive frequency, the mean depth occupied during dives also varied significantly over the course of the day in all sub-areas (all $\mathrm{K}-\mathrm{W} \chi^{2} \geq 263$, all $\mathrm{p}<0.0001$ ) (Fig. 7B). In the off-shelf waters, increases in mean dive depths were evident at 05:00 h and 19:00 h (Fig. 7B), associated with deep diving events occurring around dawn and dusk (e.g. Fig. S2A in the supplement). In the Gulf of Maine basins, Gulf of Maine Shelf, and Canadian Shelf, mean dive depth became deeper and then shallower over the course of the day, reaching maxima at 09:00 $\mathrm{h}$ to 11:00 h (post-hoc tests $\mathrm{p}<0.05$ ). Mean dive depth was generally deepest off the continental shelf, followed by the deep basins of the Gulf of Maine, and then shallower in the on-shelf waters of the Gulf of Maine and Canadian Shelf (Fig. 7B).

\section{Thermal biology}

\section{Average body temperature}

Measurements of the daily average body temperature of the bluefin tuna ranged from 14.3 to $30.3^{\circ} \mathrm{C}$ and showed strong seasonal and spatial variations. As daily mean ambient water temperature became warmer, daily mean body temperature increased (Spearman's $\rho=0.51$, $\mathrm{p}<0.0001$ ), while the thermal excess between the body and the ambient environment decreased $(\rho=-0.61, p<$ 0.0001) (Fig. 8). These relationships varied seasonally (Figs. $5 \& 8$ ) and as the fish moved from off- to on-shelf waters (Fig. S4 in the supplement at www.int-res.com/ articles/suppl/m400p245_app.pdf). During April-May when the fish were first arriving in the study region and occupying off-shelf waters, body temperature and 

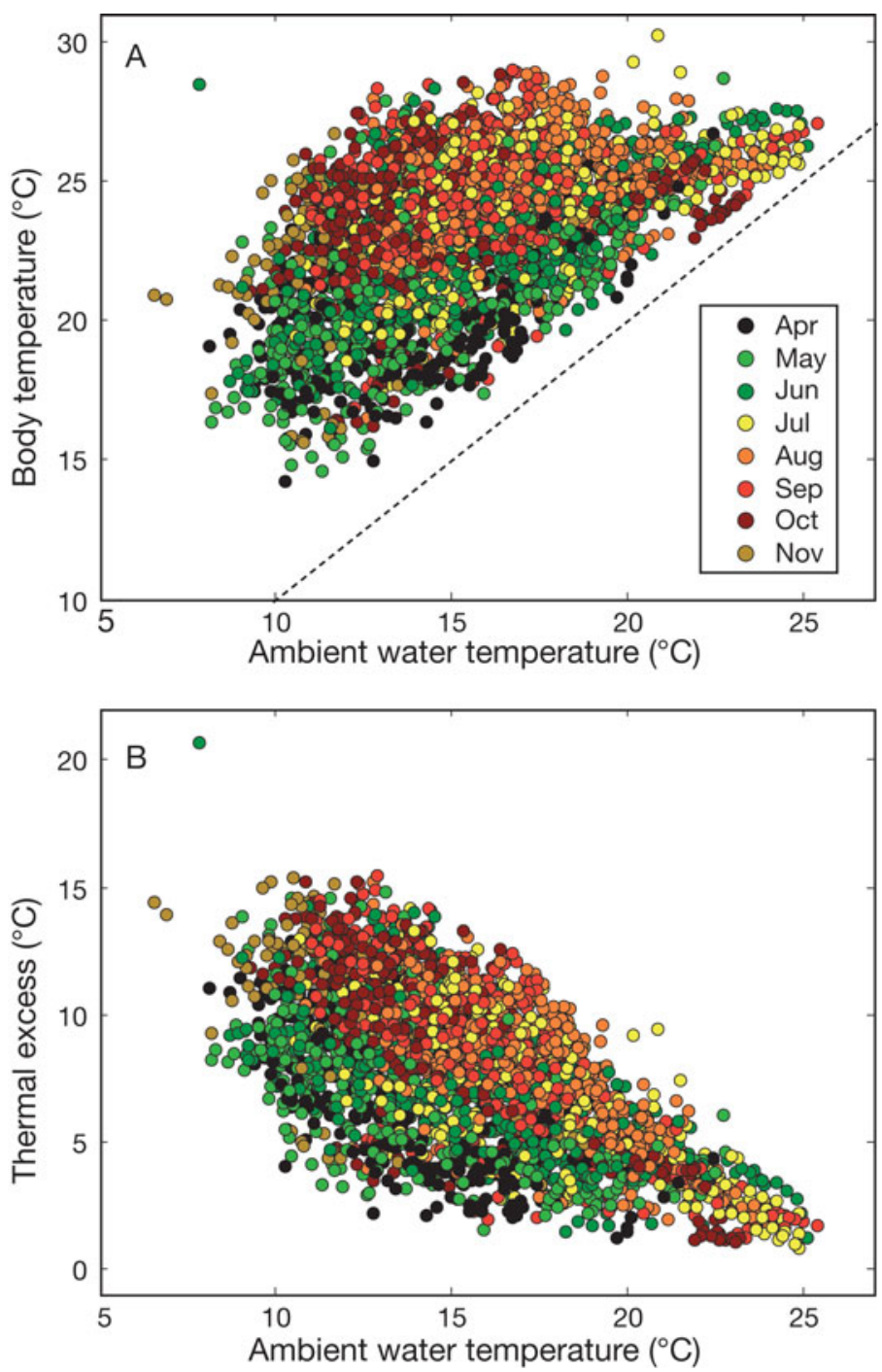

Fig. 8. Thunnus thynnus. (A) Daily mean body temperature and (B) mean thermal excess (body temperature - ambient water temperature) in relation to daily mean ambient water temperature for all days spent in the study region between April and November by the 21 (of 35) fish where measurements of internal body temperature were available. Note that body temperature was always greater than ambient temperature (dashed line: 1:1). Dot color indicates month; Fig. S4 in the supplement at www.int-res.com/articles/suppl/m400 p245_app.pdf shows these data with dot color indicating whether the fish was on- or off-shelf. Both daily mean body temperature and thermal excess were significantly correlated with daily mean ambient water temperature (Spearman's $\rho=$ 0.51 and -0.61 , respectively, $\mathrm{p}<0.0001$ )

thermal excess at a given ambient temperature were low (monthly median body temperatures of 20.2 to $21.1^{\circ} \mathrm{C}$, and thermal excesses of 6.0 to $6.9^{\circ} \mathrm{C}$ ). Body temperature and thermal excess then increased during JulyNovember $\left(23.1\right.$ to $25.2^{\circ} \mathrm{C}$ and 8.3 to $11.1^{\circ} \mathrm{C}$, respectively) when the fish were primarily in continental shelf waters (Figs. 5, 8 \& S4 in the supplement).

\section{Heat increment of feeding}

We examined 46 body temperature warming events that we hypothesize were due to the heat increment of feeding (henceforth referred to as HIF events). The typical HIF pattern is shown in Fig. 9, where archival tag measurements of body temperature increased from a minimum to a maximum thermal excess, followed by a decrease in body temperature and return towards the baseline thermal excess during a period when ambient water temperature remained relatively constant.
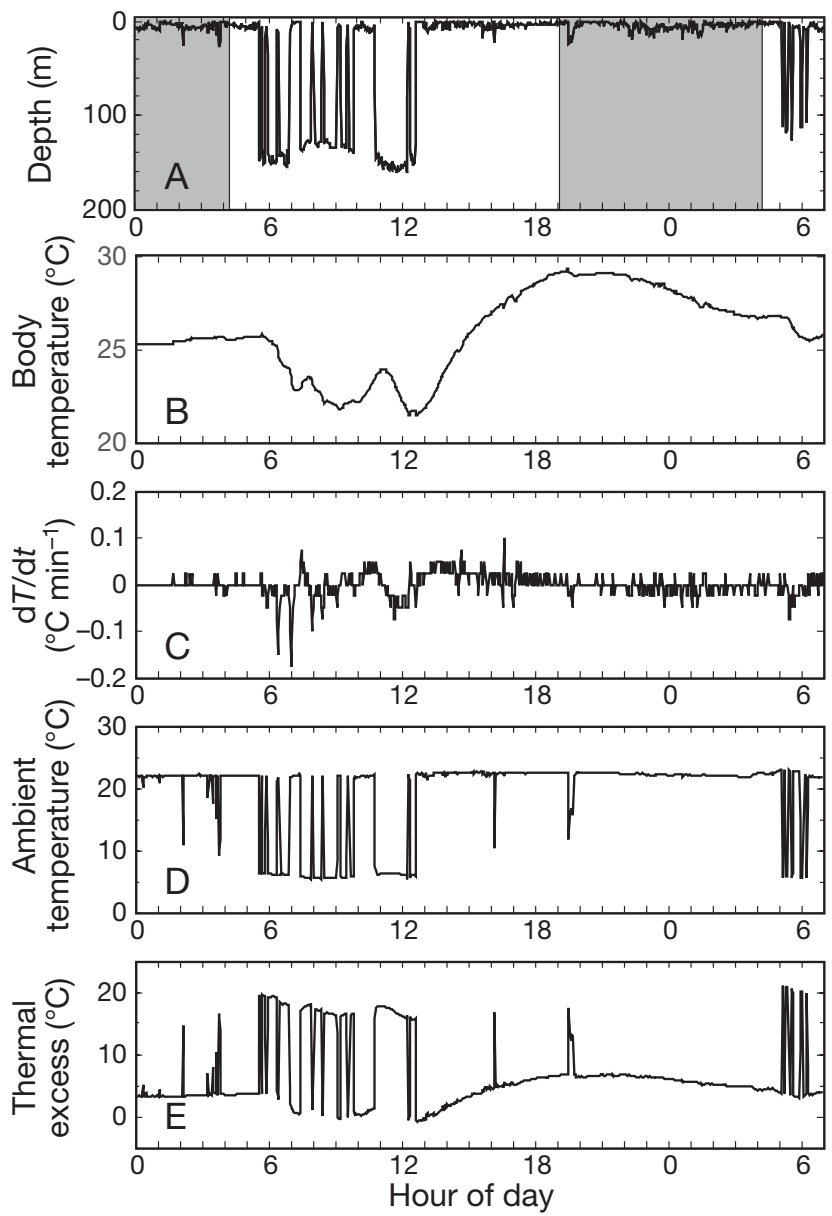

Fig. 9. Thunnus thynnus. Time-series data hypothesized to be indicative of a feeding event for the bluefin tuna implanted with archival tag 98-508, during a $30 \mathrm{~h}$ period starting at midnight on August 2, 1999. (A) Depth measurements, gray shading indicates nighttime. (B) Body temperature. (C) Rate of change of body temperature with time $(\mathrm{d} T / \mathrm{d} t)$. (D) Ambient water temperature. (E) Thermal excess (body temperature water temperature). Both thermal excess and body temperature show an increase starting at ca. noon, followed by a decrease later in the night. This pattern of an increase followed by decrease occurred during a period when the fish was at the surface and ambient water temperature was relatively constant and so does not relate to changes in ambient temperature, but rather is typical of the heat-increment associated with feeding 
The 46 HIF events analyzed occurred in 11 fish, ranging in size at the time of tagging from 180 to $222 \mathrm{~cm}$ (CFL). Many more likely HIF events were evident, but had body temperature measurements complicated by diving behaviors and conductive heat exchange with the environment. The times of onset of the steady rise in body temperature for the HIF events fell between 09:00 $\mathrm{h}$ and 20:00 $\mathrm{h}$, with a median time of onset of 13:42 $\mathrm{h}$ (Fig. 10). The maximum thermal excess attained during each event ranged from 5.8 to $13.3^{\circ} \mathrm{C}$, with a mean of $9.1^{\circ} \mathrm{C}$. The mean duration of time between warming onset and the maximum thermal excess was $7.9 \mathrm{~h}$, with a range of 2.9 to $13.6 \mathrm{~h}$.

The HIF events were typically preceded by bouts of frequent dives, followed by a surface period (e.g. Fig. 9). All of the events examined occurred in locations where temperatures in the surface mixed layer were warmer than at deeper depths, and for this analysis only one event was ever identified per day. Examining the characteristics of dives made on the day of each HIF event analyzed revealed that significantly more dives were made during the hours prior to the onset of visceral warming than after (median of 34.5 dives before onset, median of 3 dives after onset; Wilcoxon rank sum test $\mathrm{p}<0.0001$ ). The frequency of dives per hour was likewise significantly greater before, relative to after, the onset of warming (median of 2.5 dives $\mathrm{h}^{-1}$ before onset, 0.3 dives $\mathrm{h}^{-1}$ after onset; Wilcoxon rank sum test $\mathrm{p}<0.0001$ ).

\section{Bounce diving and body temperature}

As described above, during the months of June to October the bluefin tuna occupied strongly stratified waters over the continental shelf, where their dives

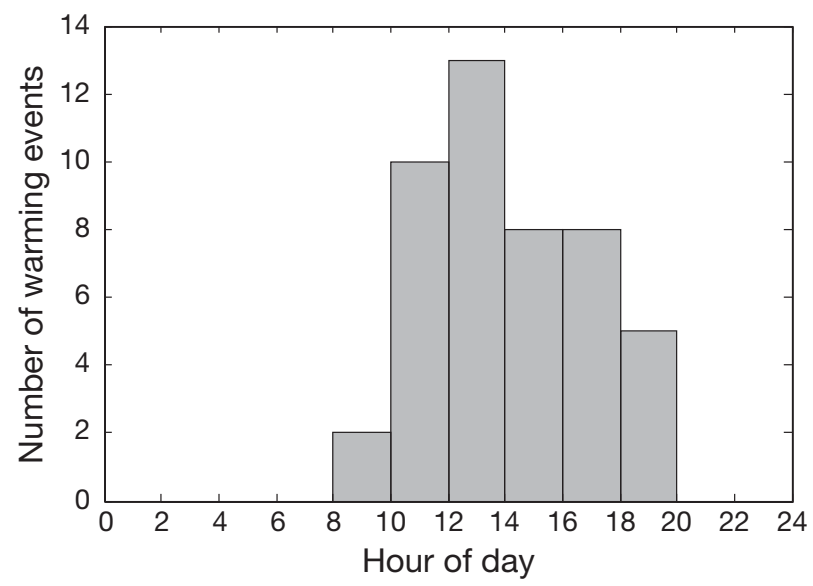

Fig. 10. Thunnus thynnus. Frequency distribution of the time of onset of 46 warming events that we associate with the heat increment of feeding. These putative feeding events were identified from archival tag measurements of body temperature made during the month of August became frequent, of short duration, and characterized by rapid descent rates (Figs. $5 \& 6$ ). Here we consider this oscillatory 'bounce diving' behavior in more detail, and in particular its potential role in thermoregulation, by examining the time-series data for an individual fish on a day when its body temperature variations associated with diving were especially pronounced (Fig. 11).

On August 2, 2004 the fish implanted with tag A2217 inhabited a water column over the Scotian Shelf where a thermal inversion was present: a warm surface mixed layer $\left(17\right.$ to $\left.18^{\circ} \mathrm{C}\right)$ underlain by a very cold layer at middepths $\left(0.7^{\circ} \mathrm{C}\right)$ and then warmer temperatures at deeper depths $\left(6^{\circ} \mathrm{C}\right)$ (Fig. 11). The fish made rapid vertical movements at descent rates of up to $3.1 \mathrm{~m} \mathrm{~s}^{-1}$ through the cold waters of the inversion into the slightly warmer temperatures below at depths of 170 to $260 \mathrm{~m}$, remaining there for durations of 19 to $63 \mathrm{~min}$ before returning to the warmer waters of the surface iso-thermal layer. Over the course of these prolonged dives and the surface intervals between dives (ranging from 17 to $45 \mathrm{~min}$ ), clear patterns of body temperature changes were evident (Fig. 11). During the time spent at depth, where ambient temperature was colder than body temperature by 13 to $17^{\circ} \mathrm{C}$, gradual decreases in body temperature of $\sim 0.01$ to $0.04^{\circ} \mathrm{C} \mathrm{min}^{-1}$ were evident. Much more rapid increases in body temperature, up to $0.1^{\circ} \mathrm{C} \mathrm{min}^{-1}$, occurred during the intervals spent in surface waters between dives, where waters were warmer than at depth but still colder than the fish's body temperature by at least $0.3^{\circ} \mathrm{C}$.

\section{DISCUSSION}

Relatively little is known about the movements of large pelagic fish through the marine pelagic realm, an environment that is more structured both in horizontal space and in depth than is often appreciated, particularly in terms of temperature. The movements of pelagic animals within this environment are generally thought to represent a balance between the maintenance of physiologically optimal temperatures, foraging demands, predation avoidance, and reproduction. To date, we are only just beginning to understand fully the relationships among these diverse energetic and environmental factors. The high resolution data available from archival-tagged fish moving undisturbed in their natural habitats are increasing our capacity to examine the interactions between the animal and its environment, over time scales of seconds to years. Our results demonstrate a strong association of the horizontal movements and vertical diving behavior of Atlantic bluefin tuna in the northwestern Atlantic with seasonal and spatial variations in the thermal structure of the water column. The tagging data also provide new 

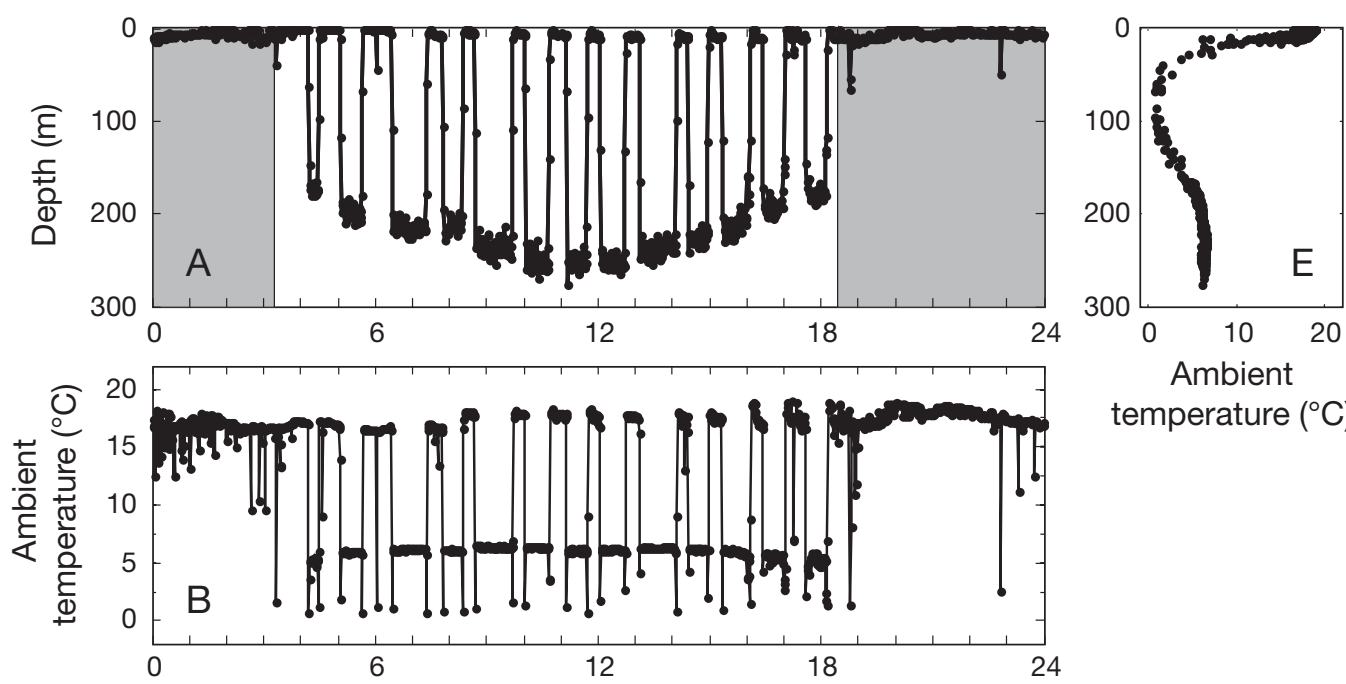

temperature $\left({ }^{\circ} \mathrm{C}\right)$

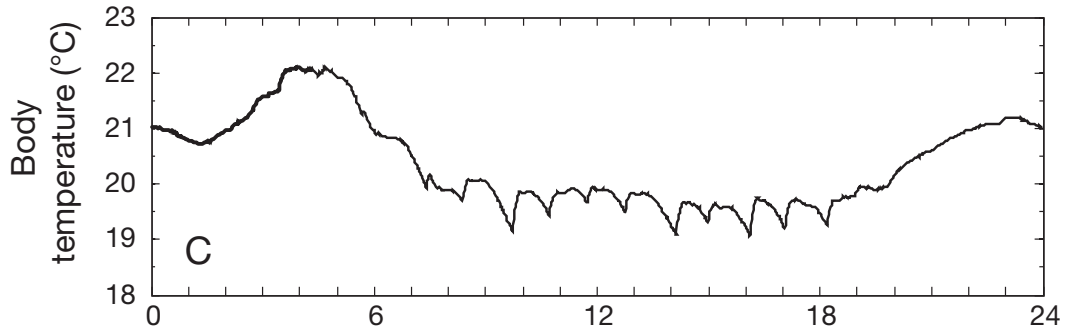

Fig. 11. Thunnus thynnus. $24 \mathrm{~h}$ time-series data from August 2, 2004 for the bluefin tuna implanted with archival tag A2217. (A) Depth, showing a regular pattern of deep dives during the day (gray indicates nighttime). (B) Ambient water temperature, indicating a strong decrease in temperature from the surface mixed layer to the colder waters below. (C) Body temperature. (D) Rate of change of body temperature with time $(\mathrm{d} T / \mathrm{d} t)$. Horizontal black line indicates $\mathrm{d} T / \mathrm{d} t=0$. (E) Ambient temperature-depth profile, based on measurements made for the same fish and time period

information on thermal and vertical limitations that, when considered in the context of our physiological knowledge of the species, will ultimately allow the development of predictive models illuminating where and when bluefin tuna travel in the North Atlantic.

\section{Horizontal movements}

The movements of Atlantic bluefin tuna are complex, varying with both age and population. Enough new information has accumulated from electronic tagging, however, that a predictable and cyclical pattern of movements in the western North Atlantic is emerging (Block et al. 2001, 2005, Wilson et al. 2005, Boustany 2006, Walli et al. 2009). During winter, electronic tagging studies of adolescent and mature fish have indicated that Atlantic bluefin tuna often occupy winter foraging grounds off North Carolina, maintaining a modal SST of 20 to $22^{\circ} \mathrm{C}$ (Boustany 2006). The fish depart these over-wintering grounds by March-April, in association with warming SSTs in this region (Boustany 2006). Some of these fish move into the central or eastern North Atlantic, but the majority move into the northwestern Atlantic region off New England (Block et al. 1998, 2001, 2005, Boustany 2006, Walli et al. 2009), before returning to North Carolina or central North Atlantic over-wintering grounds in late fall (Lutcavage et al. 1999, Stokesbury et al. 2004, Wilson et al. 2005, Teo et al. 2007).

During the spring-fall period spent at the high latitudes of the northwestern Atlantic, our results demonstrate a regular movement from off-shelf waters onto the continental shelf. By considering both tag and buoy measurements of SST, we are able to assess the conditions experienced by the fish during the periods of occupancy of off- and then on-shelf waters, and also the conditions available in each region at times before 
and after the fish were present. Bluefin tuna arrived in our northwestern Atlantic study region during AprilMay, and initially occupied relatively warm waters (monthly SST medians of 16.1 to $16.6^{\circ} \mathrm{C}$ ) off the continental shelf in the vicinity of the Norrth Wall of the Gulf Stream. Surface water temperatures on the continental shelf of the Gulf of Maine and Canadian Maritimes at this time were below $10^{\circ} \mathrm{C}$, suggesting that the off-shelf waters occupied represented the most favorable thermal habitat available as the fish moved into these higher latitude regions. Variability in occupied SST was higher during this April-May period than later in the season, likely suggesting that the fish were occupying frontal regions of variable temperature along the Gulf Stream. As SSTs on the continental shelf become warmer in June-July, and as SSTs in much of the off-shelf region began to exceed $20^{\circ} \mathrm{C}$, the bluefin tuna shifted their distribution onto the shelf. Overall, the bluefin tuna maintained a relatively constant ambient temperature regime, with monthly median SSTs inhabited varying from 16.1 to $19.0^{\circ} \mathrm{C}$ over the course of this April-September time period. Departure from the northwestern Atlantic in October-November coincided with cooling SSTs (monthly medians of 15.0 to $11.4^{\circ} \mathrm{C}$ ), again suggestive of thermal considerations influencing the movements of the fish, or potentially of their prey.

The impetus for the movement of bluefin tuna from the offshore environment onto the continental shelf likely relates to foraging. Accompanying the spatial shift from waters beyond the continental shelf to onshelf regions was an increase in the daily average body temperature of the tagged fish (monthly medians during the off-shelf period from 20.2 to $21.1^{\circ} \mathrm{C}$, and 23.1 to $25.2^{\circ} \mathrm{C}$ while on-shelf). Bluefin tuna body temperature is a function of metabolic heat production, foraging success and thus visceral warming, and heat transfer to the environment. Body temperature measurements also vary with fish size and the position of the tag within the peritoneal cavity. Despite these sources of variability, the large increase in mean body temperature for a given water temperature during July-October when the fish primarily occupied the shelf is suggestive of an increased heat increment of feeding, and increased feeding success on prey items of high caloric value, during this time period (Carey et al. 1984). Increased feeding would likely also increase the size of the bluefin tunas, and perhaps their fat content, which may play an additional role in enhancing insulation, decreasing heat loss, and increasing mean body temperature. The seasonal increase in body temperature may also relate in part to increased muscle activity levels, perhaps again associated with enhanced foraging activities. The continental shelf waters of New England and the Canadian Maritimes are highly productive during the spring-fall time period (Townsend et al. 2006), and a variety of prey species (e.g. herring, sand lance) are available in these waters (Bigelow \& Schroeder 1953, Mather et al. 1995).

Overall, our results are consistent with the Atlantic bluefin tuna having a preference for a range of SSTs centered at approximately 16 to $19^{\circ} \mathrm{C}$. Horizontal movements appear to represent a balance between this preference and access to shelf prey resources at northern latitudes that may be thermally unavailable to them at colder times of year. Recent metabolic studies of captive juvenile Pacific bluefin tuna have found a minimum metabolic rate at a temperature range of 15 to $20^{\circ} \mathrm{C}$ (Blank et al. 2007); our findings are consistent with adult Atlantic bluefin tuna potentially having a similar metabolic thermal optimum, above and below which there are increased energetic costs. The movements of the bluefin tuna thus may represent an energetic balance between occupying temperatures that carry the lowest energetic cost for maintaining routine metabolism, and gaining access to foraging opportunities. It is also possible, however, that seasonal changes in the presence or energetic quality of prey over the continental shelf may be driving the cyclical movement of bluefin tuna from off- to on-shelf regions, rather than (or perhaps in addition to) the thermal limits of the tunas.

\section{Vertical distribution}

\section{Diving behavior}

Prior studies have observed diel, seasonal, and spatial variations in the vertical behaviors of Atlantic bluefin tuna, and suggested that these may be linked to water column structure (Carey \& Olson 1982, Lutcavage et al. 2000, Wilson et al. 2005, Boustany 2006, Walli et al. 2009). In this study, we show a strong correlation between diving behavior and the thermal structure of the water column, including both ILD and the vertical thermal gradient, over seasonal time spans and broad spatial areas. In the weakly stratified waters of the offshelf region occupied during March-May, the vertical diving behavior of bluefin tuna was reduced in frequency, dives were generally deep (often in excess of $100 \mathrm{~m}$ ), and habitat below the iso-thermal layer was utilized for long periods of time. Dive frequency also showed a slight increase during the day, and the deepest dives usually occurred around dusk and dawn. Similar deep diving at dawn and dusk has been observed previously in a variety of large pelagic fishes, including bluefin tuna in the Gulf of Maine and Canadian waters (Lutcavage et al. 2000, Gunn \& Block 2001, Wilson et al. 2005) and Pacific bluefin and yellowfin (Thunnus alba- 
cares) tuna (Block et al. 1997, Marcinek et al. 2001a, Kitagawa et al. 2004, Willis et al. 2009). The motivation for this behavior remains an outstanding question, but may be associated with feeding on vertically migrating prey species, or navigation (Lutcavage et al. 2000, Marcinek et al. 2001a, Willis et al. 2009). As the bluefin tuna shifted onto the continental shelf in summer, they inhabited strongly stratified waters where their vertical behavior involved highly repetitious diving from warmer surface waters into the much colder temperatures below, targeting depths mostly much shallower than $100 \mathrm{~m}$ and remaining at these depths for short durations.

In most cases, the temperature-depth time-series data acquired by the tags indicated a relatively wellresolved water column structure (e.g. Fig. S2 in the supplement). Visual examination suggested that the ILD used in identifying dives was appropriately determined by our algorithms. In some cases, however, the temperature-depth data were much more variable, with a variety of temperatures measured at the same depth, suggestive of the fish moving between water masses of varying temperature characteristics during the course of the $6 \mathrm{~h}$ intervals over which ILD was estimated. Such cases introduce some uncertainty into our analyses of diving behavior. Overall, however, any error introduced by mis-estimation of the ILD for particular $6 \mathrm{~h}$ intervals is likely reduced by our examination of dive characteristics over a large number of dives averaged over fish, regions, and time periods.

\section{Thermoregulation}

The warmer waters of the surface mixed layer appear to represent a thermal refuge for the bluefin tuna and excursions below the mixed layer are likely limited by the impact of temperature on physiological functions. Recent physiological studies have shown that cardiac function is strongly influenced by temperature in the bluefin lineage; in particular, at cold ambient water temperatures the heart of the bluefin tuna has a pronounced bradycardia that is associated with the strong thermal sensitivity of the SERCA2 enzymes responsible for calcium ion transport in beat to beat contraction (Blank et al. 2004, Landeira-Fernandez et al. 2004, Castilho et al. 2007, Galli et al. 2009). As bluefin tuna move from warm to cold waters the capacity of the cardiac system to supply oxygen is thus reduced and the fish become more dependent upon oxygen stores in muscle tissues.

In the off-shelf waters, the small temperature differences observed between the surface and waters at depth likely reduces the cardiac challenges of occupying deeper waters, leading to dives of longer duration.
Furthermore, in the off-shelf region, the thermallyfavorable mixed layer habitat expands in depth, with temperatures from the surface to depths of up to $300 \mathrm{~m}$ remaining relatively constant. Thus, the fish can access deep depths (and the prey resources perhaps found at such depths) without leaving the surface mixed layer, leading to fewer excursions below the layer and a lower dive frequency under the dive definition employed here as excursions below the iso-thermal layer.

In contrast, in association with enhanced summertime insolation, the waters of the continental shelf become highly stratified, with much shallower mixed layers (mean \pm SD observed ILD: $21.2 \pm 13.5 \mathrm{~m}$ ) and larger thermal gradients (up to a $20^{\circ} \mathrm{C}$ difference measured between 10 and $100 \mathrm{~m}$ in depth). In order to access the cold waters below the mixed layer, the bluefin tuna make frequent returns to the surface thermal refuge, and limit their exposure to cold temperatures at depth by reducing dive durations and increasing rates of descent. During these remarkable bounce diving periods, the fish access habitats as cold as $0.04^{\circ} \mathrm{C}$. The limitation to time spent at these cold depths may ultimately relate to the total oxygen demand during dives. Although oxygen stores in the bluefin tuna are enhanced by a high-affinity myoglobin in the slow-oxidative swimming muscles (Marcinek et al. 2001b), the reduced cardiac output induced by the cold temperatures at depth may limit the capacity to meet the oxygen demands of the foraging activities conducted during dives. This potentially requires the bluefin tuna to return to warmer surface waters where the heart re-warms, heart rate and cardiac output are enhanced (Castilho et al. 2007, Galli et al. 2009), and tissues are re-oxygenated before the fish dives again (Blank et al. 2004).

The variation of diving intensity with the degree of stratification of the water column supports the hypothesis that oscillatory diving behavior is a thermoregulatory strategy. Such behavioral thermoregulation achieved through vertical movements between warm surface waters and colder waters at depth has been observed in a variety of tuna species, including Atlantic bluefin on their spawning grounds (Teo et al. 2007), Pacific bluefin (Kitagawa et al. 2000, 2001), yellowfin (Schaefer et al. 2007), and bigeye (Thunnus obesus; Holland et al. 1992). By punctuating periods at depth with surface intervals, the bluefin tuna can re-warm the heart and rapidly re-oxygenate tissues, limit overall heat loss to the environment, and maintain a warmer and less variable body temperature (Kitagawa et al. 2007). Additionally, although no temperatures of swimming muscles have been recorded in the bluefin tuna during free-swimming dives, it is probable that resurfacing also results in the maintenance of optimal core slow-twitch muscle temperatures. 
In the present study, the rapid fluctuations in ambient water temperature arising from diving and the typically short time spans (on the order of minutes) spent during dives in cold waters at depth complicate any analyses of body temperature variations that occurred over the course of individual dives. It is instructive, however, to examine the body temperature record of tag A2217 on a rare day when the fish spent protracted amounts of time at depth and when within- and between-dive variations in body temperature were especially pronounced. Steady decreases (ca. 0.01 to $0.04^{\circ} \mathrm{C} \mathrm{min}^{-1}$ ) in body temperature were observed while in the cold temperatures at depth during dives, and rapid increases (up to $0.1^{\circ} \mathrm{C} \mathrm{min}^{-1}$ ) in body temperature during between-dive intervals spent in surface waters. The faster increases than decreases in body temperature suggest a change in the whole-body heat transfer rate, perhaps due to increased heart rate in the warmer surface waters and/or to physiological regulation of the efficiency of the vascular countercurrent heat exchangers between, relative to during, dives (Holland et al. 1992, Teo et al. 2004). Since ambient temperature even in the surface waters was still colder than the fish's body temperature, the increase in body temperature must have been due to metabolic heat production. There was no suggestion that these patterns of variation in body temperature observed on this day for this fish related to feeding and digestion, rather than to changes in ambient temperature. Over the course of the middle portion of the day an oscillating pattern in body temperature resulted, and by periodically returning to the warmer surface waters, this fish ensured that body temperature never decreased below $19^{\circ} \mathrm{C}$. This variable body temperature and periodic resurfacing and re-warming behaviors are again consistent with the hypothesis that the bounce diving has a thermoregulatory function, facilitating foraging time in cold waters (Holland et al. 1992).

The hypothesis that the repeated returns by bluefin tuna to shallow mixed layer waters are thermoregulatory in nature is further supported by dive frequency being drastically reduced and dive duration increased in regions where temperatures at depth were warmer than those at the surface (i.e. a negative temperature gradient in Fig. 6B,F). When temperatures at depth are warmer than at the surface, the impetus for returning to the surface appears reduced and the periods at depth identified under our definition as dives become protracted and dive frequency thereby reduced. The fact that the bluefin tuna still do make returns to surface waters, even when such waters are colder than at depth, is noteworthy. These movements may indicate surface foraging, or may play some additional role, such as navigation or allowing the fish to assess whether a change in surface water characteristics has occurred.
Feeding

Recently, several reports have examined the foraging behavior of juvenile Pacific and Southern bluefin tuna via the HIF measured by archival tags (Itoh et al. 2003, Kitagawa et al. 2004, Walli 2007, Bestley et al. 2008). HIF events in the larger Atlantic bluefin tuna examined here were more difficult to assess because of the fish's large size and associated thermal inertia (Carey et al. 1984, Walli 2007) and the strong variations in ambient water temperature experienced by the fish as a consequence of their diving through highly stratified water columns. In this study we have only examined the most readily identifiable instances of warming events that we hypothesize were due to the HIF, typically when long periods of surface time allowed the unambiguous identification of the decrease in body temperature from its maximum. This allowed HIF events to be distinguished from warming events where no decrease was evident that may have related to the fish occupying warmer surface waters and not to feeding. It remains possible that the preliminary methods we have used to identify obvious HIF events might have biased our sample towards particular kinds of feeding-related warming events that resulted in more pronounced heat increments meeting our criteria. We also cannot fully exclude the confounding influences of heat exchange with the environment and variations in muscular activity on body temperature (Brill et al. 1994), which introduce uncertainty into our identification of putative feeding events. More conclusive analyses of feeding in these large Atlantic bluefin tuna based on analyses of body temperature might be achieved in captive facilities or pens where ambient temperature could be constrained. In the wild, such feeding analyses may await the development of new tagging technologies better suited to distinguishing among these various confounding influences.

Despite these sources of uncertainty, our analysis of 46 feeding events in the month of August suggests that the behavioral pattern of repeated diving into the colder waters below the surface mixed layer provides the bluefin tuna with access to prey resources at depth (Kitagawa et al. 2000). The onset of body temperature increases associated with the heat increment of feeding was most common at mid-day, with a median time of $1342 \mathrm{~h}$. The number and frequency of dives before these HIF events was significantly greater than after. These observations are consistent with the notion that bluefin tuna undertake bouts of morning and mid-day dives into the cold waters below the mixed layer during daytime to forage (Gunn \& Block 2001). Tunas have a well-developed sense of vision (Kawamura et al. 1981) and are likely visual foragers, and the increase in 
dive frequency during the day relative to the night may indicate that diving is a foraging behavior. Alternately, the diel change in dive frequency may relate to prey species shifting their vertical distribution between day and night, reducing the need for dives to depth during night, although if foraging did continue during night one would not expect HIF events to occur only during daytime, as observed.

Warm visceral temperatures are thought to speed digestion in bluefin tuna (Carey et al. 1984, Stevens \& McLeese 1984), and so the return to the warmer waters of the surface most likely speeds up digestion by reducing heat loss, warming the entire fish, and increasing heart rate. In a study of the heat increment of feeding in wild juvenile Pacific bluefin tuna based on archival tag data, Walli (2007) calculated a mean duration between the onset of warming to the maximum thermal excess of $13.6 \mathrm{~h}$. This is longer than the mean duration of $7.9 \mathrm{~h}$ observed here, and is perhaps indicative of different prey types and/or faster digestion in the larger Atlantic bluefin, or of the challenges of discerning when the feeding event is initiated. It was generally not possible in the present study to determine unambiguously the time at which the HIF ended and body temperature returned to baseline thermal excess, due to the fish resuming frequent diving the following day. This resumption of diving led to difficulties in distinguishing body temperature decreases due to the tail-end of the HIF from decreases due to the fish losing heat while diving into cold waters at depth.

The depths frequented during dives on and off the continental shelf provide some indication of the likely prey types the bluefin tuna are accessing in these different regions. The deeper depths targeted in off-shelf waters likely indicate feeding on meso-pelagic animals such as squid, octopus, and myctophids. The shallower depths targeted during July-October while on the continental shelf are consistent with feeding on pelagic species such as herring, squid, and mackerel. The shallower depths visited during dives on the continental shelf in many cases may also reflect bathymetric constraints, and may be suggestive of feeding on benthic prey such as sand lance or cod. Acoustic tagging studies of bluefin tuna vertical movements where bottom depth measurements were available found that in shallow regions $(<60 \mathrm{~m})$ individuals occasionally dived to within meters of the bottom (Lutcavage et al. 2000, Brill et al. 2002). Lutcavage et al. (2000) also observed dives of increasing depth as the fish moved off shallow banks $(<50 \mathrm{~m})$ into deeper waters (ca. $200 \mathrm{~m})$; diurnal variations in the depths to which the fish in the present study dived (e.g. Fig. 7B \& Fig. S2 in the supplement) may similarly relate in part to the bluefin tuna foraging along the edges of banks and other bathymetric features. Bluefin tunas are opportunistic feeders, and these inferences are supported by analyses of stomach contents of fish captured in the Gulf of Maine, which have shown a variety of prey types and a preponderance of herring and sand lance (Chase 2002).

\section{SUMMARY}

This study capitalized on high resolution time-series measurements of depth and temperature collected by electronic tags to demonstrate variability in the horizontal movements and diving behavior of Atlantic bluefin tuna on their northwestern Atlantic foraging grounds strongly associated with variations in the vertical temperature structure of the water column inhabited. Both the timing of the horizontal seasonal shift of the bluefin tuna onto the continental shelf from off-shelf waters and the short-term vertical excursions (i.e. dives) made from the warm and shallow mixed layer into the cold waters below appear to relate to a trade-off between the thermal constraints of preferred and metabolically-favorable ambient temperatures and accessing the increased prey resources found on relative to off the shelf and below relative to within the mixed layer. The tunas thus appear to be making short- and long-term behavioral decisions concerning their horizontal and vertical habitat that balance optimal foraging with thermal constraints on physiology. Future studies might similarly examine how Atlantic bluefin tuna diving behavior relates to environmental conditions elsewhere in the species' range; the different thermal structures and depth distributions of prey in regions other than the northwestern Atlantic are likely to modify the patterns observed here. Understanding the horizontal and vertical movements of the bluefin tuna in relation to oceanographic conditions and foraging success will be key to developing the habitat utilization and ecosystem models that will be necessary for the more effective management of the dwindling populations of this species.

Acknowledgements. We acknowledge the dedication and commitment of the Tag-A-Giant scientific team, both in the field and lab, as well as the captains and crew of all participating fishing and research vessels. We thank Drs. H. Bailey, S. Bograd, A. Boustany, S. Jorgensen, S. Teo, Y. Tremblay, A. Walli, K. Weng, and S. Wilson who provided much appreciated advice, assistance, and code for various analyses. We also thank staff and technicians from the Tuna Research and Conservation Center of the Monterey Bay Aquarium who helped in the field portion of the research inclusive of $\mathrm{C}$. Farwell, D. Fudge, R. Schallert, A. Seitz, T. Sippel, and T. Williams. The helpful comments of 4 anonymous reviewers are also appreciated. This work was funded by NOAA, the Tag-A-Giant Foundation, the Lenfest Foundation, and the Monterey Bay Aquarium Foundation. 


\section{LITERATURE CITED}

Arnold GP, Dewar H (2001) Electronic tags in marine research: a 30-year perspective. In: Sibert JR, Nielsen JL (eds) Electronic tagging and tracking in marine fisheries. Kluwer Academic Publishers, Dordrecht, p 7-64

Bestley S, Patterson TA, Hindell MA, Gunn JS (2008) Feeding ecology of wild migratory tunas revealed by archival tag records of visceral warming. J Anim Ecol 77: 1223-1233

Bigelow HB, Schroeder CS (1953) Fishes of the Gulf of Maine. Fishery Bulletin 74, United States Government Printing Office, Washington, DC

Blank JM, Morrissette JM, Landeira-Fernandez AM, Blackwell SB, Williams TD, Block BA (2004) In situ cardiac performance of Pacific bluefin tuna hearts in response to acute temperature change. J Exp Biol 207:881-890

Blank JM, Morrissette JM, Farwell CJ, Price M, Schallert RJ, Block BA (2007) Temperature effects on metabolic rate of juvenile Pacific bluefin tuna Thunnus orientalis. J Exp Biol 210:4254-4261

Block BA, Keen JE, Castilo B, Dewar H and others (1997) Environmental preferences of yellowfin tuna (Thunnus albacares) at the northern end of its range. Mar Biol 130: 119-132

Block BA, Dewar H, Farwell C, Prince ED (1998) A new satellite technology for tracking the movements of Atlantic bluefin tuna. Proc Natl Acad Sci USA 95:9384-9389

Block BA, Dewar H, Blackwell SB, Williams TD and others (2001) Migratory movements, depth preferences, and thermal biology of Atlantic bluefin tuna. Science 293: 1310-1314

Block BA, Teo SLH, Walli A, Boustany A and others (2005) Electronic tagging and population structure of Atlantic bluefin tuna. Nature 434:1121-1127

Boustany A (2006) An examination of population structure, movement patterns and environmental preferences in northern bluefin tuna. PhD dissertation, Stanford University, Palo Alto, CA

Boustany AM, Reeb CA, Block BA (2008) Mitochondrial DNA and electronic tracking reveal population structure of Atlantic bluefin tuna (Thunnus thynnus). Mar Biol 156: $13-24$

Brill RW, Dewar H, Graham JB (1994) Basic concepts relevant to heat transfer in fishes, and their use in measuring the physiological thermoregulatory abilities of tunas. Environ Biol Fishes 40:109-124

Brill R, Lutcavage M, Metzger G, Bushnell P and others (2002) Horizontal and vertical movements of juvenile bluefin tuna (Thunnus thynnus), in relation to oceanographic conditions of the western North Atlantic, determined with ultrasonic telemetry. Fish Bull 100:155-167

Carey FG, Lawson KD (1973) Temperature regulation in free swimming bluefin tuna. Comp Biochem Physiol A 44: 375-392

Carey FG, Olson RJ (1982) Sonic tracking experiments with tuna. Col Vol Sci Pap ICCAT 17:458-466

Carey FG, Kanwisher JW, Stevens ED (1984) Bluefin tuna (Thunnus thynnus) warm their viscera during digestion. J Exp Biol 109:1-20

Carlsson J, McDowell JR, Carlsson JEL, Graves JE (2007) Genetic identity of YOY bluefin tuna from the eastern and western Atlantic spawning areas. J Hered 98:23-28

Castilho PC, Landeira-Fernandez AM, Morrissette J, Block BA (2007) Elevated $\mathrm{Ca}^{2+}$ ATPase (SERCA2) activity in tuna hearts: comparative aspects of temperature dependence. Comp Biochem Physiol A 148:124-132
Chase BC (2002) Differences in diet of Atlantic bluefin tuna (Thunnus thynnus) at five seasonal feeding grounds on the New England continental shelfs. Fish Bull 100: $168-180$

Galli GLJ, Lipnick MS, Block BA (2009) The effect of thermal acclimation on action potentials and sarcolemmal $\mathrm{K}+$ channels from Pacific bluefin tuna cardiomyocytes. Am J Physiol Regul Integr Comp Physiol 297:R502-R509

Gunn JS, Block BA (2001) Advances in acoustic, archival and satellite tagging of tunas. In: Block BA, Stevens ED (eds) Tunas: ecological physiology and evolution. Academic Press, San Diego, CA, p 167-224

Gunn J, Hartog J, Rough K (2001) The relationship between food intake and visceral warming in southern bluefin tuna (Thunnus maccoyii): Can we predict how much tuna has eaten from archival tag data? In: Sibert JR, Nielsen JL (eds) Electronic tagging and tracking in marine fisheries. Kluwer Academic Publishers, Dordrecht, p 109-130

Hill RD, Braun MJ (2001) Geolocation by light-level, the next step: latitude. In: Sibert JR, Nielsen JL (eds) Electronic tagging and tracking in marine fisheries. Kluwer Academic Publishers, Dordrecht, p 443-456

Holland KN, Brill RW, Chang RKC, Sibert JR, Fournier DA (1992) Physiological and behavioral thermoregulation in bigeye tuna (Thunnus obesus). Nature 358:410-412

ICCAT (International Commission for the Conservation of Atlantic Tunas) (2007) Report of the 2006 Atlantic bluefin tuna stock assessment session. Col Vol Sci Pap ICCAT 60: $652-880$

Itoh T, Tsuji S, Nitta A (2003) Swimming depth, ambient water temperature preference, and feeding frequency of young Pacific bluefin tuna (Thunnus orientalis) determined with archival tags. Fish Bull 101:535-544

Kara AB, Rochford PA, Hurlburt HE (2000) An optimal definition for ocean mixed layer depth. J Geophys Res C 105:16803-16821

Kawamura G, Hishimura W, Ueda S, Nishi T (1981) Vision in tunas and marlins. Mem Kagoshima Univ Res Center S Pac 1:3-47

Kitagawa T, Nakata H, Kimura S, Itoh T, Tsuji S, Nitta A (2000) Effect of ambient temperature on the vertical distribution and movement of Pacific bluefin tuna Thunnus thynnus orientalis. Mar Ecol Prog Ser 206:251-260

Kitagawa T, Nakata H, Kimura S, Tsuji S (2001) Thermoconservation mechanisms inferred from peritoneal cavity temperature in free-swimming Pacific bluefin tuna Thunnus thynnus orientalis. Mar Ecol Prog Ser 220:253-263

Kitagawa T, Kimura S, Nakata H, Yamada H (2004) Diving behavior of immature, feeding Pacific bluefin tuna (Thunnus thynnus orientalis) in relation to season and area: the East China Sea and the Kuroshio-Oyashio transition region. Fish Oceanogr 13:161-180

Kitagawa T, Boustany AM, Perle CR, Farwell CJ, Williams TM, Dewar H, Block BA (2007) Horizontal and vertical movements of juvenile bluefin tuna (Thunnus orientalis) in relation to seasons and oceanography in the eastern Pacific. Fish Oceanogr 16:409-421

Kurota H, McAllister MK, Lawson GL, Nogueira JL, Teo SLH, Block BA (2009) A sequential Bayesian methodology to estimate movement and exploitation rates using electronic and conventional tag data: application to Atlantic bluefin tuna (Thunnus thynnus). Can J Fish Aquat Sci 66: 321-342

Landeira-Fernandez AM, Morrissette JM, Blank JM, Block BA (2004) Temperature dependence of the $\mathrm{Ca}^{2+}$ ATPase (SERCA2) in the ventricles of tuna and mackerel. Am J Physiol Regul Integr Comp Physiol 286:R398-R404 
Lutcavage M, Brill R, Skomal G, Chase B, Howey P (1999) Results of pop-up satellite tagging of spawning size class fish in the Gulf of Maine: Do North Atlantic bluefin tuna spawn in the mid-Atlantic? Can J Fish Aquat Sci 56: 173-177

Lutcavage M, Brill R, Skomal GB, Chase BC, Goldstein JL, Tutein J (2000) Tracking adult North Atlantic bluefin tuna (Thunnus thynnus) in the northwestern Atlantic using ultrasonic telemetry. Mar Biol 137:347-358

MacKenzie BR, Mosegaard H, Rosenberg AA (2009) Impending collapse of bluefin tuna in the northeast Atlantic and Mediterranean. Conserv Lett 2:26-34

Marcinek DJ, Blackwell SB, Dewar H, Freund EV and others (2001a) Depth and muscle temperature of Pacific bluefin tuna examined with acoustic and pop-up satellite archival tags. Mar Biol 138:869-885

Marcinek DJ, Bonaventura J, Wittenberg JB, Block BA (2001b) Oxygen affinity and amino acid sequence of myoglobins from endothermic and ectothermic fish. Am J Physiol Regul Integr Comp Physiol 280:R1123-R1133

Mather FJ, Mason JM, Jones AC (1995) Life history and fisheries of Atlantic bluefin tuna. NOAA Tech Mem NMFS-SEFSC 370

Neilson JD, Campana SE (2008) A validated description of age and growth of western Atlantic bluefin tuna (Thunnus thynnus). Can J Fish Aquat Sci 65:1523-1527

NMFS (National Marine Fisheries Service) (1995) Final environmental impact statement for regulatory amendment for the western Atlantic bluefin tuna fishery. NMFS, Silver Springs, MD

NRC (National Research Council) (1994) An assessment of Atlantic bluefin tuna. National Acadamy Press, Washington, DC

Rooker JR, Secor DH, deMetrio G, Schloesser R, Block BA, Neilson JD (2008) Natal homing and connectivity in Atlantic bluefin tuna populations. Science 322:742-744

Schaefer KM, Fuller DW, Block BA (2007) Movements, behavior, and habitat utilization of yellowfin tuna (Thunnus albaceres) in the northeastern Pacific Ocean, ascertained through archival tag data. Mar Biol 152:503-525

Siegel S, Castellan NJ (1988) Nonparametric statistics for the behavioral sciences. McGraw-Hill, New York

Editorial responsibility: Hans Heinrich Janssen,

Oldendorf/Luhe, Germany
Stevens ED, McLeese JM (1984) Why bluefin tuna have warm tummies: temperature effect on trypsin and chymotrypsin. Am J Physiol 246:R487-R494

Stokesbury MJW, Teo SLH, Seitz A, O'Dor RK, Block BA (2004) Movement of Atlantic bluefin tuna (Thunnus thynnus) as determined by satellite tagging experiments initiated off New England. Can J Fish Aquat Sci 61: 1976-1987

Teo SLH, Boustany A, Blackwell S, Walli A, Weng KC, Block BA (2004) Validation of geolocation estimates based on light level and sea surface temperature from electronic tags. Mar Ecol Prog Ser 283:81-98

Teo SLH, Boustany A, Dewar H, Stokesbury MJW and others (2007) Annual migrations, diving behavior, and thermal biology of Atlantic bluefin tuna, Thunnus thynnus, on their Gulf of Mexico breeding grounds. Mar Biol 151:1-18

Townsend DW, Thomas AC, Mayer LM, Thomas MA, Quinlan JA (2006) Oceanography of the Northwest Atlantic continental shelf. In: Robinson AR, Brink KH (eds) The sea, Vol 14. Harvard University Press, Cambridge, MA, p 119-168

Walli AG (2007) On the movements, aggregations and the foraging habitat of bluefin tuna (Thunnus thynnus \& orientalis). PhD dissertation, University of California Santa Cruz, Santa Cruz, CA

Walli A, Teo SLH, Boustany A, Farwell CJ and others (2009) Seasonal movements, aggregations and diving behavior of Atlantic bluefin tuna (Thunnus thynnus) revealed with archival tags. PLoS ONE 4:e6151

Willis J, Phillips J, Muheim R, Diego-Rasilla JD, Hobday AJ (2009) Spike dives of juvenile southern bluefin tuna (Thunnus maccoyii): A navigational role? Behav Ecol Sociobiol 64:57-68

Wilson RP, Ducamp JJ, Rees GW, Culik BM, Niekamp K (1992) Estimation of location: global coverage using light intensity. In: Priede IG, Swift SM (eds) Wildlife telemetry: remote monitoring and tracking of animals. Ellis Horwood, London, p 131-134

Wilson SG, Lutcavage ME, Brill RW, Genovese MP, Cooper AB, Everly AW (2005) Movements of bluefin tuna (Thunnus thynnus) in the northwestern Atlantic Ocean recorded by pop-up satellite archival tags. Mar Biol 146:409-423

Submitted: March 17, 2009; Accepted: October 29, 2009 Proofs received from author(s): February 8, 2010 